\title{
Modelling chemotherapy effects on granulopoiesis
}

\author{
Sibylle Schirm ${ }^{1,2}$, Christoph Engel ${ }^{1}$, Markus Loeffler ${ }^{1}$ and Markus Scholz ${ }^{1,2^{*}}$
}

\begin{abstract}
Background: Although the growth-factor G-CSF is widely used to prevent granulotoxic side effects of cytotoxic chemotherapies, its optimal use is still unknown since treatment outcome depends on many parameters such as dosing and timing of chemotherapies, pharmaceutical derivative of G-CSF used and individual risk factors. We showed in the past that a pharmacokinetic and -dynamic model of G-CSF and human granulopoiesis can be used to predict the performance of yet untested G-CSF schedules. However, only a single chemotherapy was considered so far. In the present paper, we propose a comprehensive model of chemotherapy toxicity and combine it with our cell kinetic model of granulopoiesis. Major assumptions are: proportionality of cell numbers and cell loss, delayed action of chemotherapy, drug, drug-dose and cell stage specific toxicities, no interaction of drugs and higher toxicity of drugs at the first time of application. Correspondingly, chemotherapies can be characterized by a set of toxicity parameters which can be estimated by fitting the predictions of our model to clinical time series data of patients under therapy. Data were either extracted from the literature or were received from cooperating clinical study groups.

Results: Model assumptions proved to be feasible in explaining granulotoxicity of 10 different chemotherapeutic drugs or drug-combinations applied in 33 different schedules with and without G-CSF. Risk groups of granulotoxicity were traced back to differences in toxicity parameters.

Conclusion: We established a comprehensive model of combined G-CSF and chemotherapy action in humans which allows us to predict and compare the outcome of alternative G-CSF schedules. We aim to apply the model in different clinical contexts to optimize and individualize G-CSF treatment.
\end{abstract}

Keywords: Leukopenia, G-CSF, Filgrastim, Pegfilgrastim, Chemotherapy

\section{Background}

The effectivity of antineoplastic chemotherapy of some cancer types, such as lymphomas or breast cancer, depends on dose density of applied cytostatic drugs [1-6]. Dose density is defined as the amount of drug given per body surface per time unit $\left(\mathrm{mg} / \mathrm{m}^{2} /\right.$ week $)[7,8]$. It has been shown that a decrease in dose density such as treatment delays or dose reductions, can have negative impact on remission rates, recurrence rates and overall survival rates [9-15].

Physicians are frequently forced to reduce dose density due to serious chemotherapy-associated side effects, of which neutropenia, i.e. a reduction of white blood cells, is the most common one. Because neutrophils are an essential part of the nonspecific immune system, neutropenic patients are prone to bacterial and fungal

\footnotetext{
* Correspondence: markus.scholz@imise.uni-leipzig.de

${ }^{1}$ Institute for Medical Informatics, Statistics and Epidemiology (IMISE) Medical Faculty, University of Leipzig, Haertelstraße 16-18, 04107 Leipzig, Germany ¿2LIFE Research Center, Leipzig, Germany
}

infections, frequently resulting in an increased need of antibiotics, prolonged hospitalization and a higher risk of therapy discontinuation [16-22].

To ameliorate neutropenia, the recombinant haematopoietic growth factor G-CSF (granulocyte colony stimulating factor) is routinely applied. It is a major requirement to make dose-dense therapies feasible. G-CSF increases the mitotic activity, accelerates the maturation of different immature granuloid precursor cells in the bone marrow and increases the release of mature granulocytes into blood [23,24]. Nowadays, a variety of pharmaceutical derivatives of G-CSF are available differing in pharmacokinetic and -dynamic properties. In consequence, combined chemotherapy and G-CSF treatment result in complex dynamics of granulocytes due to the interaction of G-CSF pharmacokinetics, G-CSF induced granulocytosis via different mechanisms and chemotherapy induced cell destruction.

We recently established a biomathematical model of G-CSF applications in humans explaining numerous 
scenarios of G-CSF applications of the most frequently used derivatives Filgrastim and Pegfilgrastim into healthy volunteers and first simple chemotherapies [25]. However, the large variety of chemotherapies supported by G-CSF in current clinical practice is not yet covered.

In the present article we introduce a substantially refined model of chemotherapy action applicable for different diseases and risk groups. The major objective of our model is to allow predictions of the dynamics of granulocytes after combined chemotherapy and G-CSF applications especially regarding effects of alternative, yet untested G-CSF treatment schedules on neutropenia.

\section{Methods}

We recently developed a comprehensive model of pharmacokinetics and pharmacodynamics of Filgrastim and Pegfilgrastim [25]. We briefly sketch this model in the following:

\section{PK/PD model structure and basic properties}

Figure 1 depicts the structure of the PK/PD-model. Granulopoiesis is divided into five distinct cell compartments, representing haematopoietic stem cells $(S)$, early progenitors (CG), proliferating precursors (PGB), maturing precursors (MGB) and mature granulocytes in circulation (GRA). Dynamics of each compartment are described by ordinary differential equations (ODE). The system is regulated by several feed-back loops, mostly mediated by the cytokine G-CSF. Endogenous
G-CSF production is regulated by the cell demand of the system.

All granulopoietic cells originate from the stem cell compartment. Cell division and differentiation rates in $\mathrm{S}$ are regulated in such a way that self-maintenance gains priority in case of low stem cell numbers. Cells committed to granulopoietic lineages enter the subsequent compartment CG, which represents the most immature cell stage committed to granulopoiesis. The next compartment, PGB, represents the mitotic granuloid precursors (myeloblasts, promyelocytes and myelocytes). Compartment MGB represents all non-mitotic precursors (metamyelocytes, banded cells and mature neutrophils) in the bone marrow. The final compartment, GRA, comprises all mature neutrophils in the peripheral blood. Reductions of lymphocytes LY due to chemotherapy are also modelled.

Without chemotherapy, changes of compartment sizes are determined by balance equations of cell influx, cell production and cell efflux or degradation:

$$
\frac{d C(t)}{d t}=C_{i n}(t) * A(t)-\frac{C(t)}{T(t)}
$$

where $\frac{d C(t)}{d t}$ represents the changing rate of compartment size, $C_{i n}(t)$ represents the cell influx rate from the preceding compartment, $A(t)$ the amplification of cell numbers and $T(t)$ is the average time of a cell residing in the compartment (transition time).

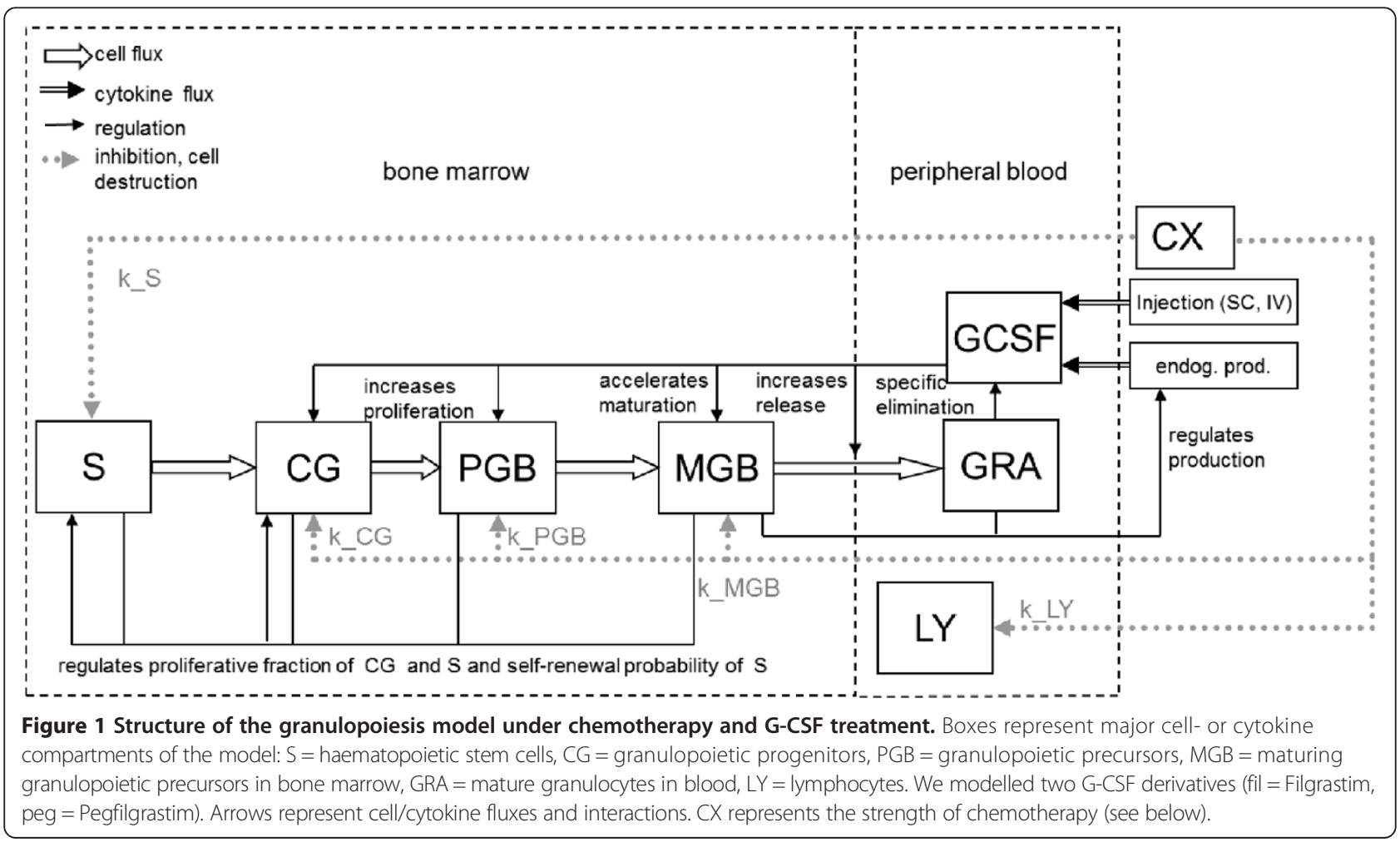


Filgrastim and Pegfilgrastim are assumed to have different pharmacodynamic properties in the model, whereas Filgrastim and endogenous G-CSF are assumed to be undistinguishable. Amplification rate and transition time in PGB increase with G-CSF serum concentration. In contrast, the transition time in MGB and the apoptosis rate are reduced with increasing G-CSF concentrations. Details of Filgrastim and Pegfilgrastim pharmacokinetics, pharmacodynamics, and corresponding regulatory processes are described elsewhere [25].

On the basis of this baseline model, we aim at developing a more comprehensive model of cytotoxic chemotherapy action on granulopoiesis. Corresponding assumptions and equations are explained in the following. Some detailed information can be found in [26].

\section{Modeling chemotherapy}

Next we present and discuss our assumptions reagarding chemotherapy modelling in detail.

\section{Assumption 1 (injection)}

Injection of chemotherapy is modeled by pulse functions according to the applied dosing and timing schedules. In general, each drug is modeled by a separate pulse function, where the length of the pulse corresponds to the injection time and the amplitude is normalized in such a way that the area under the curve after a single injection equals one (see equations below).

\section{Assumption 2 (delayed action)}

We assumed a delayed maximum of chemotherapy damage after injection. This is modeled in a phenomenological rather than mechanistic way by a set of concatenated first order transitions resulting in a delayed maximum after injection (see [27]).

$$
\begin{aligned}
& \frac{\mathrm{d} \Psi_{\mathrm{drug}}^{(\mathrm{i})}(\mathrm{t})}{\mathrm{dt}}=\Psi_{\text {drug }_{\text {out }}}^{(i-1)}(\mathrm{t})-\mathrm{k}_{\text {Delay }}^{\mathrm{drug}} \Psi_{\text {tox }}^{\mathrm{i}}(\mathrm{t}), \quad i \\
& =1, \ldots, 4 \text {, with } \\
& \Psi_{\text {drug }}^{(0)}(\mathrm{t})=\mathrm{CHEMO}^{\text {drug }}(\mathrm{t}), \\
& \operatorname{CHEMO}^{\text {drug }}(\mathrm{t})=\sum_{i=1}^{N^{\text {cycle }}}\left(\mathrm{Hv}\left(\mathrm{t}-\mathrm{t}_{\mathrm{i}}\right)-\mathrm{Hv}\left(\mathrm{t}-\mathrm{t}_{\mathrm{i}}-\mathrm{t}_{\text {inf }}\right)\right) / \mathrm{t}_{\text {inf }} \\
& \Psi_{\text {drug }_{\text {out }}}^{(i)}(\mathrm{t})=\mathrm{k}_{\text {Delay }}^{\text {drug }} \Psi_{d r u g}^{(i)}(\mathrm{t}), \quad i=1, \ldots, 4,
\end{aligned}
$$

where $\mathrm{Hv}$ is the Heavyside function: $H \mathrm{v}(\mathrm{t})=\left\{\begin{array}{l}0: t \leq 0 \\ 1: t>0\end{array}, \mathrm{t}_{\mathrm{i}}\right.$ are the time points of chemotherapy applications and $t_{\text {inf }}$ is the infusion time. Thus, function CHEMO represents the chemotherapy schedule. In summary, $\Psi_{\text {drug }_{\text {out }}}^{(4)}(t)$ represents the strength of the (delayed) toxic effect.

\section{Assumption 3 (toxicity)}

Drug, drug-dose and cell-stage specific toxicity functions are derived from $\Psi_{\text {drug }_{\text {out }}}^{(4)}(\mathrm{t})$ by multiplications with specific toxicity values: $\mathrm{K}_{\mathrm{X}}^{\mathrm{drug}}(t)$

$$
\Psi_{\text {drug }}^{\mathrm{X}}(\mathrm{t})=\mathrm{K}_{\mathrm{X}}^{\mathrm{drug}}(t) \Psi_{\text {drug }_{\text {out }}}^{(4)}(\mathrm{t})
$$

The quantities $K_{X}^{\text {drug }}$ are called toxicity coefficients in the following.

\section{Assumption 4 (first cycle effect)}

The term "first cycle effect" refers to increased toxicity of chemotherapeutic drugs when applied for the first time. Accordingly, we assumed a 'first cycle effect' by multiplying the toxicity of the first chemotherapy cycle by a factor $f_{c} \geq 1$. Hence,

$$
\mathrm{K}_{\mathrm{X}}^{\mathrm{drug}}(t)=\left\{\begin{array}{cc}
f_{f_{c}}^{d r u g} \mathrm{~K}_{\mathrm{X}}^{\mathrm{drug}} & \text { if } t<t_{2}^{\mathrm{drug}} \\
\mathrm{K}_{\mathrm{X}}^{\mathrm{drug}} & \text { else }
\end{array}\right.
$$

\section{Assumption 5 (no interactions between drugs)}

Most chemotherapy regimens consist of multiple drugs administered simultaneously. If toxicity functions of single drugs are available, the resulting total toxicity is obtained by adding these functions. Thus, in general, no interactions between single drugs are assumed:

$$
\Psi_{\text {total }}^{\mathrm{X}}(\mathrm{t})=\sum_{\text {drug }} \Psi_{\text {drug }}^{\mathrm{X}}
$$

where "drug" summarizes all drugs applied in combination. The overall process of defining toxicity functions is sketched in Figure 2.

\section{Assumption 6 (cell loss)}

Cytotoxic drugs cause a depletion of bone marrow cells. The loss rate is proportional to the number of cells in each compartment (first order kinetics). The overall toxicity function $\Psi_{\text {total }}^{\mathrm{X}}(t)$ defined above serves as proportionality factor, i.e.:

$$
\frac{d C_{X}(t)}{d t}=C_{X}^{i n}(t) * A(t)-\frac{C_{X}(t)}{T(t)}-\Psi_{\text {total }}^{\mathrm{X}}(t) C_{X}(t)
$$

where $C_{X}$ ist the content of compartment $X$.

\section{Assumption 7 (risk groups)}

Risk groups of patients with differing toxic response can be described by different sets of corresponding toxicity parameters. Motivated by the observation that G-CSF response does not differ between elderly and younger patients [28], we assumed the same cell kinetic parameters among risk groups. 


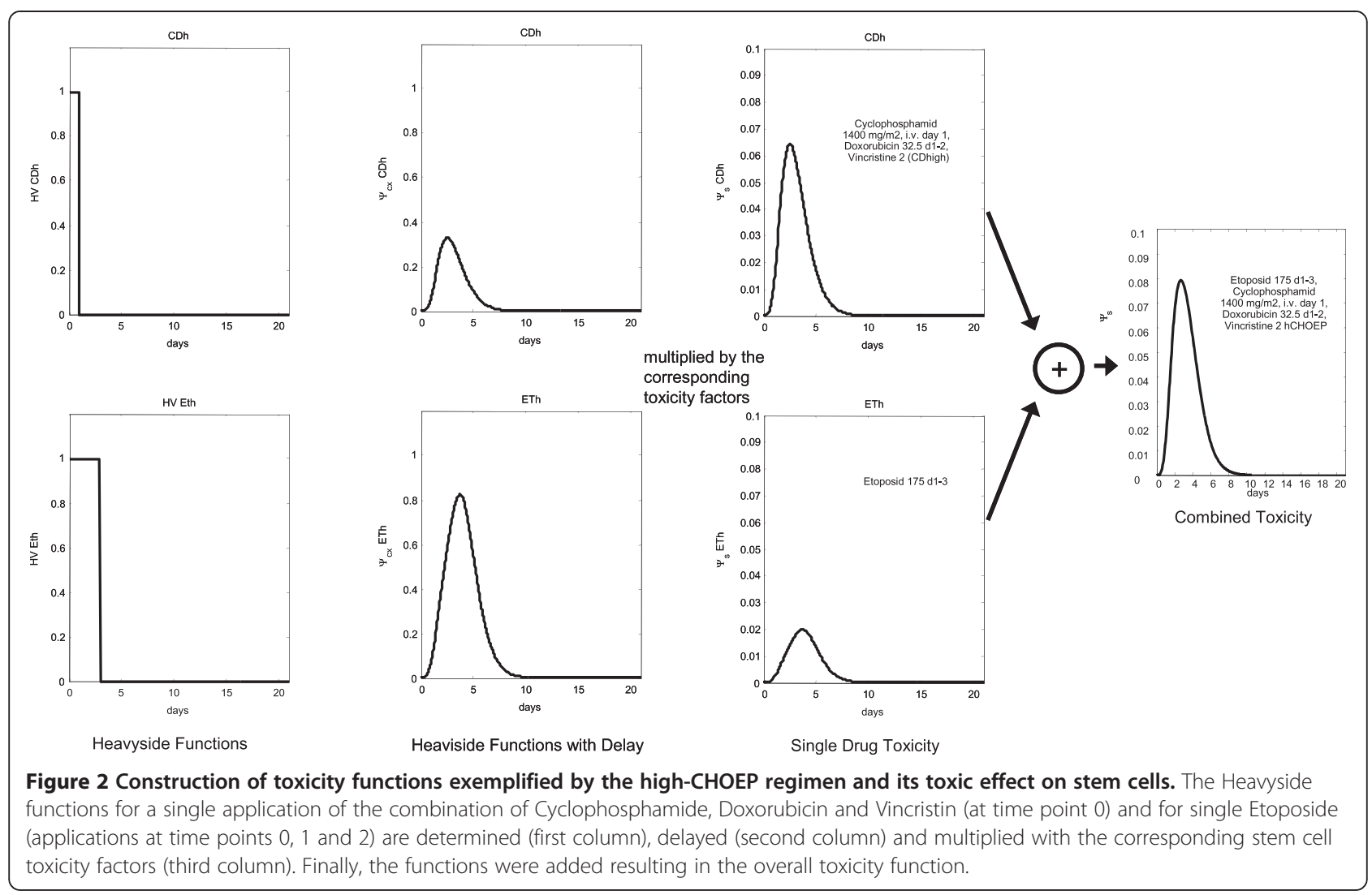

\section{Assumption 8 (lymphopoiesis)}

Depletion of lymphocytes is modelled by the following simple equation:

$$
C_{W B C}(t)=C_{A N C}(t)+C_{L Y} * e^{-\Psi_{L Y}(t)}
$$

$C_{W B C}, C_{A N C}$ and $C_{L Y}$ are the concentrations of white blood cells, neutrophils and lymphocytes in peripheral blood. The factor $e^{-\Psi_{L Y}(t)}$ quantifies the overall cytoreductive effect of chemotherapy on lymphocytes. $\Psi_{L Y}(t)$ is analogously defined as toxicities regarding granulopoiesis. Note that lymphocyte dynamics are not explicitly modelled except for this chemotherapy effect. Thus, $C_{L Y}=3000 / \mu l$ is constant, i.e. the normal concentration of lymphocytes.

\section{Assumption 9 (Prednisone)}

Prednisone is a chemotherapeutic drug without cytotoxic effect. It is often applied for the treatment of malignant lymphoma (e.g., CHOP, CHOEP, highCHOEP and BEACOPP, see Table 1, "Summary of modelled chemotherapies"). It is well known that prednisone temporarily increases granulocyte counts caused by temporarily prolonged half-life [29-31].

\section{Assumption 10 (Cell kinetic parameters are un-affected by chemotherapy)}

Besides the above mentioned (toxic) effects of chemotherapy, it is assumed that all cell-kinetic parameters of our granulopoiesis model remain unchanged. Specifically, we do not assume irreversible deterioration of granulopoiesis or reduced G-CSF response of cell stages during or after chemotherapy.

\section{Clinical data}

Since the toxic effects of chemotherapies on bone marrow cannot directly be observed, at least one clinical dataset of patients under therapy is required to estimate it. Different schedules of the chemotherapy and different schedules of supportive G-CSF treatment provide additional information which can be used to improve toxicity estimates or to validate model predictions. Data of G-CSF application into healthy volunteers were already used to validate our pharmacokinetic and -dynamic model of G-CSF [25].

Data of 10 different chemotherapies used to treat Hodgkin's lymphoma (HD), non-Hodgkin's disease (NHL), breast cancer (BC) and non-small cell lung cancer (NSCLC) are available (Table 1), either from literature or from cooperating clinical study groups (German Hodgkin's Lymphoma Study Group (Professor Engert), 
Table 1 Summary of modelled chemotherapies: we present names of therapies and corresponding dosage of drugs

\begin{tabular}{|c|c|c|c|c|c|c|c|c|c|c|}
\hline Drug & CHOP & CHOEP & High-CHOEP & BEACOPP & BEACOPP esc. & TA & ETC & EC-T & ESHAP & Carboplatin + Paclitaxel \\
\hline Bleomycin $\left(\mathrm{mg} / \mathrm{m}^{2}\right)$ & & & & 10 & 10 & & & & & \\
\hline Carboplatin & & & & & & & & & & variable \\
\hline Cisplatin $\left(\mathrm{mg} / \mathrm{m}^{2}\right)$ & & & & & & & & & 25 & \\
\hline Cyclophosphamid $\left(\mathrm{mg} / \mathrm{m}^{2}\right)$ & 750 & 750 & 1400 & 650 & 1250 & & 2500 & 600 & & \\
\hline Cytarabin $\left(\mathrm{mg} / \mathrm{m}^{2}\right)$ & & & & & & & & & 2000 & \\
\hline Docetaxel $\left(\mathrm{mg} / \mathrm{m}^{2}\right)$ & & & & & & 75 & & & & \\
\hline Doxorubicin $\left(\mathrm{mg} / \mathrm{m}^{2}\right)$ & 50 & 50 & 32.5 & 25 & 35 & 60 & & & & \\
\hline Etoposide $\left(\mathrm{mg} / \mathrm{m}^{2}\right)$ & & 100 & 175 & 100 & 200 & & & & 40 & \\
\hline Epirubicin $\left(\mathrm{mg} / \mathrm{m}^{2}\right)$ & & & & & & & 150 & 90 & & \\
\hline Methyl-prednisolon (mg) & & & & & & & & & 500 & \\
\hline Paclitaxel $\left(\mathrm{mg} / \mathrm{m}^{2}\right)$ & & & & & & & 225 & 175 & & 225 \\
\hline Prednison (mg) & 100 & 100 & 100 & 100 & 100 & & & & & \\
\hline Procarbacine $\left(\mathrm{mg} / \mathrm{m}^{2}\right)$ & & & & 100 & 100 & & & & & \\
\hline Vincristine (mg) & 2 & 2 & 2 & 2 & 2 & & & & & \\
\hline
\end{tabular}

German High-Grade Non-Hodgkin's Lymphoma Study Group (Professor Pfreundschuh), German Breast Group (Professor von Minckwitz)). Considering different cytotoxic drug and G-CSF schedules, data of 33 different chemotherapies are available (Table 2).

Data sets comprise time series data of G-CSF serum concentrations, ANC or WBC of patients under therapy. For modelling issues, we used patient's medians throughout.

\section{Parameter estimation}

Pharmakokinetic and pharmakodynamic parameters for Filgrastim and Pegfilgrastim are described elsewhere and remained unchanged in the present work [25]. In our model, the toxicity of a chemotherapy regimen is characterised by a set of cell-stage and drug specific toxicity parameters (for S, CG, PGB, MGB, LY) and a drug specific delay parameter. Parameter estimation was realised using an algorithm based on evolutionary strategies. Evolutionary strategies are stochastic algorithms used for numerical optimization [48]. The cost function to calculate model fitness was defined as:

$$
\int_{t_{0}}^{t_{1}}\left|\log f_{\text {model }}(t, \mathrm{k})-\log f_{\text {data }}(t)\right| d t \rightarrow \min
$$

where $t_{0}$ is the time of the first data point, $t_{1}$ is the last data point, $f_{\text {model }}(t, \mathrm{k})$ is the solution of the model equation system for the granulocyte compartment at the time of $t\left(t_{0} \leq t \leq t_{1}\right)$ based on the parameter set $k=\left\{k_{1}\right.$, $\left.\ldots, k_{n}\right\}$ and $f_{\text {data }}(t)$ is the linearly interpolated data curve. Agreement of logarithms was pursued since cell counts are usually log-normally distributed.

We split the data of the NHL trial (CHOP-like chemotherapies of high-grade non-Hodgkin's disease) into young and elderly patients to account for risk specific toxicities (chemotherapy assumption 7, see above). The toxicity parameters were estimated in a stepwise manner starting with simple chemotherapies which require only a few parameters estimates. More complex chemotherapies were modelled by estimating toxicity parameter sets for yet unconsidered drugs or drug combinations. Toxicity parameters estimated in earlier fitting steps were kept constant throughout the fitting process. The parameters for the first cycle effect and the two delay parameters are kept constant for different dose levels and for young and elderly patients as well. If drugs are always applied in combinations, it is impossible to separate the toxic effects of its components. In these cases, a single set of toxicity parameters was estimated for the combination.

In more detail:

1. We estimated $\mathrm{CHOP}$ parameters separately for elderly patients (scenarios 13, 15, 21, 30, 31 of Table 2, chemotherapy dosings can be found in Table 1), and young patients (scenarios 14, 20, 33). We assumed higher toxicity for elderly patients [49].

2. Using CHOEP data sets and the parameters found in step 1, we determined parameter settings for Etoposide $100 \mathrm{mg} / \mathrm{m}^{2}$ for young (scenarios 16,23 ) and elderly patients (scenarios 17, 24).

3. Using BEACOPP basis data sets 18 and 26 and the parameters for Etoposide 100 for young patients estimated in step 2 we determined parameter settings for the combination of Cyclophosphamide $650 \mathrm{mg} / \mathrm{m}^{2}$, Doxorubicin $25 \mathrm{mg} / \mathrm{m}^{2}$ and Vincristine $2 \mathrm{mg}$, with the constraint that the parameter values of this combination must be smaller than those for CHOP 
Table 2 Clinical data sets used for modelling: we present disease, chemotherapy protocol and corresponding G-CSF schedules

\begin{tabular}{|c|c|c|c|c|c|}
\hline & G-CSF derivative & Administration & Disease & Chemotherapy & Reference \\
\hline 01 & Filgrastim & $5 \mu \mathrm{g} / \mathrm{kg}$, days 2-13 & Breast cancer & TA & {$[32]$} \\
\hline 02 & Filgrastim & $5 \mu \mathrm{g} / \mathrm{kg}$, days $2-6$ & NSCLC & $\mathrm{CP}$ & [33] \\
\hline 03 & Filgrastim & $480 \mu \mathrm{g} / \mathrm{kg}$, days 6-13 & $\mathrm{NHL}$ & high-CHOEP-14* & [34] \\
\hline 04 & Pegfilgrastim & 30 g/kg, day 2 & Breast cancer & TA & [32] \\
\hline 05 & Pegfilgrastim & $60 \mu \mathrm{g} / \mathrm{kg}$, day 2 & Breast cancer & TA & [32] \\
\hline 06 & Pegfilgrastim & $100 \mu \mathrm{g} / \mathrm{kg}$, day 2 & Breast cancer & TA & [32] \\
\hline 07 & Pegfilgrastim & $6000 \mu \mathrm{g} / \mathrm{kg}$, day 2 & Breast cancer & TA & {$[35]$} \\
\hline 08 & Pegfilgrastim & $6000 \mu \mathrm{g} / \mathrm{kg}$, day 2 & Breast cancer & TA & {$[36]$} \\
\hline 09 & Pegfilgrastim & $30 \mu \mathrm{g} / \mathrm{kg}$, day 2 & NSCLC & $\mathrm{CP}$ & [33] \\
\hline 10 & Pegfilgrastim & $100 \mu \mathrm{g} / \mathrm{kg}$, day 2 & NSCLC & $\mathrm{CP}$ & [33] \\
\hline 11 & Pegfilgrastim & $300 \mu \mathrm{g} / \mathrm{kg}$, day 2 & NSCLC & $\mathrm{CP}$ & [33] \\
\hline 12 & Pegfilgrastim & $6000 \mu \mathrm{g} / \mathrm{kg}$, day 2 & $\mathrm{NHL}$ & CHOP-14 & {$[37]$} \\
\hline 13 & Pegfilgrastim & $6000 \mu \mathrm{g} / \mathrm{kg}$, day 2 & DLBCL & R CHOP-14 & {$[38]$} \\
\hline 14 & - & - & $\mathrm{NHL}$ & CHOP-21* (young) & [39] \\
\hline 15 & - & - & $\mathrm{NHL}$ & CHOP-21* (elderly) & {$[40]$} \\
\hline 16 & - & - & $\mathrm{NHL}$ & CHOEP-21* (young) & [39] \\
\hline 17 & - & - & $\mathrm{NHL}$ & CHOEP-21* (elderly) & {$[40]$} \\
\hline 18 & - & - & $\mathrm{HD}$ & BEACOPP-21* & {$[41]$} \\
\hline 19 & - & - & Breast cancer & $E C-T^{*}$ & {$[42]$} \\
\hline 20 & Filgrastim & $480 \mu \mathrm{g} / \mathrm{kg}$, days $4-13$ & $\mathrm{NHL}$ & CHOP-14* (young) & [39] \\
\hline 21 & Filgrastim & $480 \mu \mathrm{g} / \mathrm{kg}$, days $4-13$ & $\mathrm{NHL}$ & CHOP-14* (elderly) & {$[40]$} \\
\hline 22 & Filgrastim & $480 \mu \mathrm{g} / \mathrm{kg}$, days 6-12 & $\mathrm{NHL}$ & $\mathrm{CHOP}-14^{*}$ & [43] \\
\hline 23 & Filgrastim & $480 \mu \mathrm{g} / \mathrm{kg}$, days $4-13$ & $\mathrm{NHL}$ & CHOEP-14* (young) & [39] \\
\hline 24 & Filgrastim & $480 \mu \mathrm{g} / \mathrm{kg}$, days $4-13$ & $\mathrm{NHL}$ & CHOEP-14* (elderly) & {$[40]$} \\
\hline 25 & Filgrastim & $480 \mu \mathrm{g} / \mathrm{kg}$, days $6-13$ & $\mathrm{NHL}$ & high-CHOEP-21* & [43] \\
\hline 26 & Filgrastim & $480 \mu \mathrm{g} / \mathrm{kg}$, days $8-13$ & $\mathrm{HD}$ & BEACOPP-14* & {$[44]$} \\
\hline 27 & Filgrastim & $480 \mu \mathrm{g} / \mathrm{kg}$, days 8-15 & $\mathrm{HD}$ & BEACOPP-21 escalated* & {$[41]$} \\
\hline 28 & Filgrastim & $480 \mu \mathrm{g} / \mathrm{kg}$, days 3-10 & Breast cancer & $\mathrm{E}-\mathrm{T}-\mathrm{C}^{*}$ & {$[42]$} \\
\hline 29 & Filgrastim & $5 \mu \mathrm{g} / \mathrm{kg}$, days 5-16 & relapsed or persistent $\mathrm{HD}$ or $\mathrm{NHL}$ & ESHAP & {$[45]$} \\
\hline 30 & Pegfilgrastim & $6000 \mu \mathrm{g} / \mathrm{kg}$, day 2 & $\mathrm{NHL}$ & $\mathrm{CHOP}-14^{*}$ & {$[46]$} \\
\hline 31 & Pegfilgrastim & $6000 \mu \mathrm{g} / \mathrm{kg}$, day 4 & $\mathrm{NHL}$ & $\mathrm{CHOP}-14^{*}$ & {$[46]$} \\
\hline 32 & Pegfilgrastim & $100 \mu \mathrm{g} / \mathrm{kg}$, day 6 & relapsed or persistent $\mathrm{HD}$ or $\mathrm{NHL}$ & ESHAP & [45] \\
\hline 33 & Pegfilgrastim & $6000 \mu \mathrm{g} / \mathrm{kg}$, day 2 & DLBCL & R CHOP-14 & {$[47]$} \\
\hline
\end{tabular}

Scenarios with access to raw data are denoted with*.

young (because of lower or equal dosage of Cyclophosphamide, Doxorubicine and Vincristine compared to CHOP). Parameters for Bleomycin $10 \mathrm{mg} / \mathrm{m}^{2}$ and Procarbacine $100 \mathrm{mg} / \mathrm{m}^{2}$ were also determined.

4. With the data set 27 (BEACOPP escalated) the parameter settings for the combination of Cyclophosphamide $1250 \mathrm{mg} / \mathrm{m}^{2}$, Doxorubicin $35 \mathrm{mg} / \mathrm{m}^{2}$ and Vincristine $2 \mathrm{mg}$, and for Etoposide
$200 \mathrm{mg} / \mathrm{m}^{2}$ were estimated with the constraint that the parameter values must be larger than those estimated for BEACOPP basis.

5. Taking the high-CHOEP data sets 3 and 25, we estimated parameters for the combination Cyclophosphamide $1400 \mathrm{mg} / \mathrm{m}^{2}$, Doxorubicin $32.5 \mathrm{mg} / \mathrm{m}^{2}$ and Vincristine $2 \mathrm{mg}$, and for Etoposide $175 \mathrm{mg} / \mathrm{m}^{2}$ with the constraint that parameter values must be larger than for CHOEP young. 
6. Independently of the previous settings, parameters are determined for Doxorubicin $60 \mathrm{mg} / \mathrm{m}^{2}$ and Docetaxel $75 \mathrm{mg} / \mathrm{m}^{2}$ using data sets $1,4-8$.

7. Using data sets 2, 9-11, parameters are determined for the combination of Carboplatin and Paclitaxel $225 \mathrm{mg} / \mathrm{m}^{2}$.

8. Using simultaneously the data sets of E-T-C (data set 28) and EC-T (data set 19), the parameter settings for Epirubicin (dose $90 \mathrm{mg} / \mathrm{m}^{2}$ or $150 \mathrm{mg} / \mathrm{m}^{2}$ ), Paclitaxel (dose $175 \mathrm{mg} / \mathrm{m}^{2}$ or $225 \mathrm{mg} / \mathrm{m}^{2}$ ) and Cyclophosphamide (dose $600 \mathrm{mg} / \mathrm{m}^{2}$ or $2500 \mathrm{mg} / \mathrm{m}^{2}$ ) were determined with the constraint that lower doses have lower values of toxicity parameters.

9. With the ESHAP data set 29, parameter settings for Etoposide $40 \mathrm{mg} / \mathrm{m}^{2}$, Cytarabine $2000 \mathrm{mg} / \mathrm{m}^{2}$ and Cisplatin $25 \mathrm{mg} / \mathrm{m}^{2}$ were determined.

Three scenarios were not used for parameter estimation and served as model validation: WBC data from non Hodgkin lymphoma patients treated with CHOP-14 and Filgrastim on day 6-12 (data set 22), ANC data of patients with relapsed or persistent HD or NHL, treated with ESHAP and Pegfilgrastim $100 \mu \mathrm{g} / \mathrm{kg}$ on day 6 (data set 32) and WBC and G-CSF serum level data from non Hodgkin lymphoma patients treatet with CHOP-14 and Pegfilgrastim $6000 \mu \mathrm{g}$ on day 2 (data set 12).

\section{Quantification of myelotoxicity}

In order to compare toxicity of different chemotherapy and G-CSF scenarios, it is necessary to quantify the degree of reduction of granulocytes during the course of the therapy. There is evidence that the risk for infectious complications in neutropenic patients depends on the depth as well as on the duration of neutropenia [50,51]. Therefore, we defined the area between a certain threshold and the model curve below the threshold (AOC) as an appropriate summary measure for neutropenia/leukopenia or severity of reduction of other bone marrow cell stages. We used $2.000 / \mu \mathrm{l}$ and $4.000 / \mu \mathrm{l}$ as thresholds for total cell counts of neutrophils and leukocytes respectively. For normalized cell counts we always use the steady-state value 1 as threshold. The AOC was either used to compare overall toxicity between schedules or served as a target measure for optimizing G-CSF schedules.

\section{Technical implementation}

The model equations were programmed and solved on a standard personal computer using the numeric computation software Matlab 7.5.0.342 (R2007b) and the integrated Simulink toolbox v7.0 (The MathWorks, Natick, MA). Model simulations were performed by numerical integration of the ODE system. For our model, evaluation of functions is expensive. Therefore, we used the variable step solver from Adams and Bashford (ode113).

\section{Results}

Applying our model, we simulated 14 different chemotherapy scenarios (TA, CP, CHOP-14, CHOP-21, CHOEP14, CHOEP-21, high CHOEP-14, high CHOEP-21, BEACOPP-14, BEACOPP-21, BEACOPP escalated, EC-T, E-T-C, and ESHAP) including 14 different drugs. Taking into account individual risk groups, we estimated a total of 12 different parameter sets. Considering different schedules of Pegfilgrastim and Filgrastim, 33 scenarios were modelled. First, we study the qualitative behaviour of our resulting chemotherapy model.

\section{Qualitative behaviour of the chemotherapy model}

In Figure 3, we studied the behaviour of our chemotherapy model on the basis of simplified chemotherapy actions. The estimated parameter set for $\mathrm{CHOP}$ in elderly patients was considered for this purpose. At first, the effect of an isolated stem cell kill imposed by the CHOP chemotherapy is simulated (Figure 3A). As a result, the stem cells are diminished quickly, while the later cell stages decrease with some delay. After mild oscillations, the cell counts approach normal levels.

Next, we simulated an isolated CHOP chemotherapy effect on the compartment PGB alone (Figure 3B). PGB decrease immediately, and, after certain delay, other cell stages are reduced too. After oscillation, the cell counts return to normal levels similar to the isolated stem cell kill.

In Figure $3 \mathrm{C}$ we show the results of $\mathrm{CHOP}$ toxicity affecting all cell stages. This toxic effect is equivalent to later simulations of clinical scenarios involving CHOP. The figure shows that due to the combined toxicity on all cell stages, the compartment CG is most seriously affected. Recovery of the system takes much more time than in the above mentioned scenarios.

\section{Simulations of simple chemotherapies}

According to step 1 of our estimation procedure, we fitted parameters of simple chemotherapy scenarios first. Simple chemotherapies refer to those comprising either a small number of different cytotoxic drugs or drug combinations applied at the same time. This applies for data sets $1-12,13-17,20,21,23-25,30,31$ and 33 , where only one or two toxicity parameters per cell stage are required to describe the therapy. As example, a comparison of model and data for the CHOP and CHOEP young scenarios with and without G-CSF treatment can be found in Figure 4. Other scenarios can be found in the appendix, Additional file 1: Figures A3-A8. Estimated parameter sets (Table 3) resulted in a good agreement of model and data.

\section{Chemotherapy model: more complex chemotherapy simulations}

In the next step, more complex chemotherapies containing a higher number of cytotoxic drugs or more complex 
A

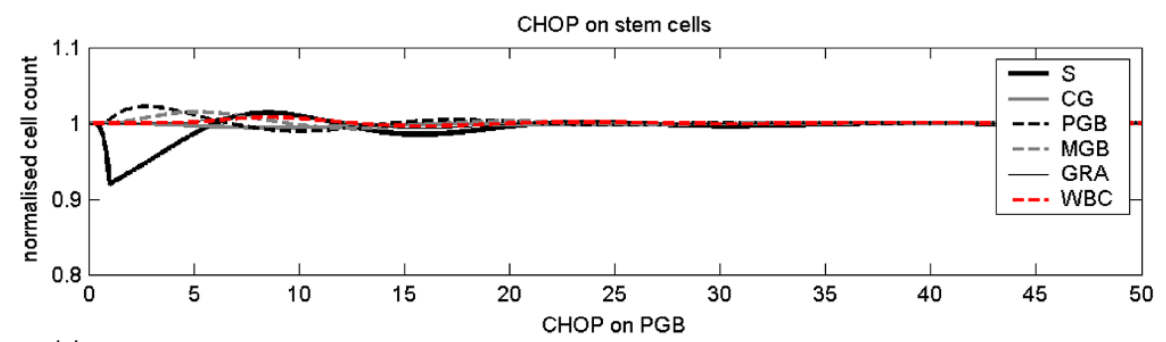

B

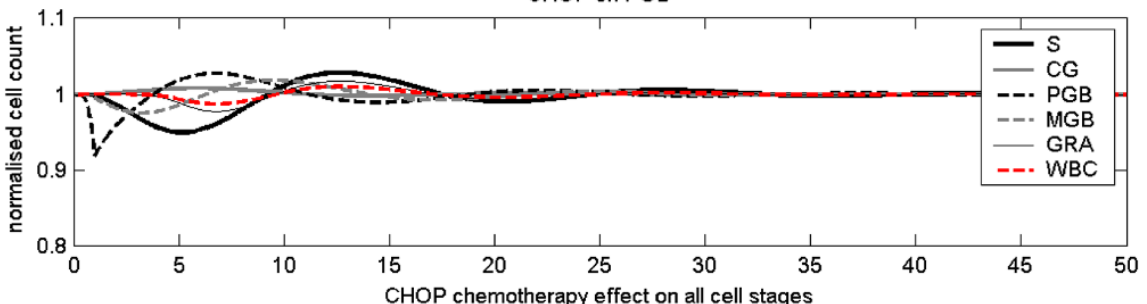

C

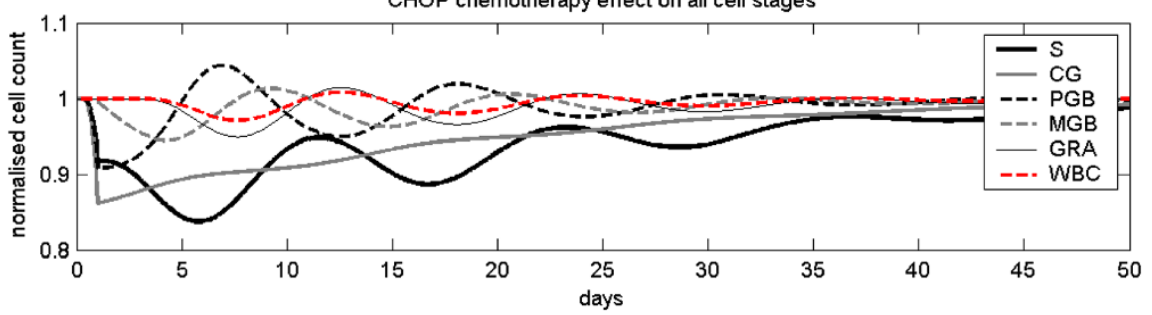

Figure 3 Toxicity of CHOP chemotherapy. Time courses of normalised cell counts of different cell stages after a single application of CHOP chemotherapy. A: CHOP effect only on stem cells. B: CHOP effect only on PGB. C: CHOP effect on all cell stages.
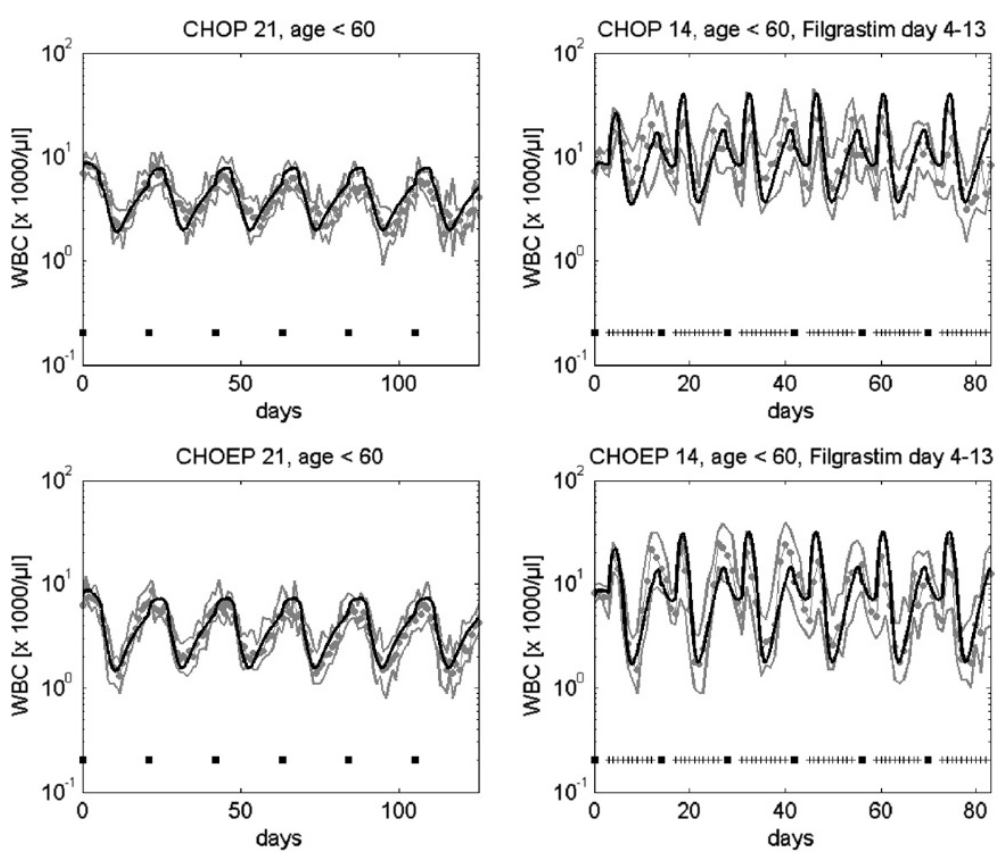

Figure 4 Simulation results for CHOP-21, CHOP-14, CHOEP-21, CHOEP-14, younger patients. We show simulated cell counts for CHOP and CHOEP chemotherapy. Dots represent patient medians, grey lines represent interquartile range of patient data, black squares correspond to chemotherapy administrations, "+" correspond to days with G-CSF-injections. Clinical data originate from our collaborating clinical trials group [39], see Table 2. 
Table 3 Toxicity parameters: Each drug or drug-combination is characterized by a set of eight parameters

\begin{tabular}{|c|c|c|c|c|c|c|c|c|c|}
\hline & & $\begin{array}{l}\mathrm{FC} \\
(\mathrm{txFC})\end{array}$ & $\begin{array}{l}\text { Delay } \\
\text { (Deltx) }\end{array}$ & $\mathrm{S}(\mathrm{txS})$ & $\begin{array}{l}\text { CG } \\
(\mathrm{t} \times \mathrm{CG}) \\
\end{array}$ & $\begin{array}{l}\text { PGB } \\
(\mathrm{txPGB})\end{array}$ & $\begin{array}{l}\text { MGB } \\
\text { (txMGB) }\end{array}$ & $\begin{array}{l}\text { Delay WBC } \\
\text { (Deltx...wbc) }\end{array}$ & $\begin{array}{l}\text { tox WBC } \\
\text { (txWBC) }\end{array}$ \\
\hline $\begin{array}{l}\text { Cyclophosphamid } 750 \mathrm{mg} / \mathrm{m}^{2} \mathrm{~d} 1 \text {, Doxorubicin } 50 \mathrm{mg} / \mathrm{m}^{2} \mathrm{~d} 1 \text {, } \\
\text { Vincristine } 2 \mathrm{mg} \text { d1 (CHOPo) }\end{array}$ & CHOP, age $>60$ & $1.11 \mathrm{E}+00$ & $6.35 \mathrm{E}-02$ & $2.16 \mathrm{E}-01$ & $3.70 \mathrm{E}-01$ & $2.34 \mathrm{E}-01$ & $1.69 \mathrm{E}-04$ & $1.37 \mathrm{E}-02$ & $1.27 \mathrm{E}+01$ \\
\hline Etoposide 100 mg/m²/d d1-3 (ETo) & CHOEP, age $>60$ & $1.10 E+00$ & $6.84 \mathrm{E}-02$ & 2.69E-04 & $1.97 \mathrm{E}-02$ & $1.04 \mathrm{E}+00$ & $3.00 \mathrm{E}-06$ & $3.50 \mathrm{E}-02$ & 7.49E-01 \\
\hline $\begin{array}{l}\text { Cyclophosphamid } 750 \mathrm{mg} / \mathrm{m}^{2} \mathrm{~d} 1 \text {, Doxorubicin } 50 \mathrm{mg} / \mathrm{m}^{2} \mathrm{~d} 1 \text {, } \\
\text { Vincristine } 2 \mathrm{mg} \text { d1 (CHOPy) }\end{array}$ & $\mathrm{CHOP}$, age $<60$ & $1.11 \mathrm{E}+00$ & $6.35 \mathrm{E}-02$ & 1.94E-01 & $3.70 \mathrm{E}-01$ & 1.06E-01 & 1.30E-04 & 1.37E-02 & $1.08 \mathrm{E}+01$ \\
\hline Etoposide 100 mg/m²/d d1-3 (ETy) & BEACOPP, CHOEP, age $<60$ & $1.10 E+00$ & $6.84 \mathrm{E}-02$ & $1.91 \mathrm{E}-04$ & $5.46 \mathrm{E}-03$ & 4.02E-01 & $2.00 \mathrm{E}-06$ & $3.50 \mathrm{E}-02$ & $9.30 \mathrm{E}-02$ \\
\hline Procarbazine 100 mg/m²/d, d1-7 (PROC) & BEACOPP (escalated) & $1.09 \mathrm{E}+00$ & 1.30E-02 & 2.42E-03 & $1.03 \mathrm{E}-02$ & 5.19E-02 & $7.80 \mathrm{E}-05$ & $1.00 \mathrm{E}-05$ & $1.00 \mathrm{E}-05$ \\
\hline $\begin{array}{l}\text { Cyclophosphamid } 650 \mathrm{~d} 1 \text {, Doxorubicin } 25 \mathrm{mg} / \mathrm{m}^{2} \mathrm{~d} 1 \text {, } \\
\text { Vincristine } 2 \mathrm{mg} \text { d } 1(\mathrm{CD})\end{array}$ & BEACOPP & $1.11 E+00$ & $6.35 \mathrm{E}-02$ & 6.47E-04 & 3.70E-01 & $1.48 \mathrm{E}-02$ & 4.10E-05 & $1.37 \mathrm{E}-02$ & $1.08 \mathrm{E}+01$ \\
\hline Bleomycin 10 mg/m² (VB) & BEACOPP (escalated) & $1.32 \mathrm{E}+00$ & 3.33E-03 & $1.20 \mathrm{E}-02$ & $3.01 \mathrm{E}-02$ & $1.57 \mathrm{E}-02$ & $6.00 \mathrm{E}-06$ & & \\
\hline $\begin{array}{l}\text { Cyclophosphamid } 1250 \mathrm{mg} / \mathrm{m}^{2} \mathrm{~d} 1 \text {, Doxorubicin } 35 \mathrm{mg} / \mathrm{m}^{2} \mathrm{~d} 1 \text {, } \\
\text { Vincristine } 2 \mathrm{mg} \text { d1 (CDesk) }\end{array}$ & BEACOPP escalated & $1.11 \mathrm{E}+00$ & $6.35 \mathrm{E}-02$ & 2.12E-01 & 3.70E-01 & 2.27E-01 & $1.84 \mathrm{E}-04$ & 1.37E-02 & $1.09 \mathrm{E}+01$ \\
\hline Etoposide 200 mg/m²/d d1-3 (ETesk) & BEACOPP escalated & $1.10 E+00$ & $6.84 \mathrm{E}-02$ & $1.91 \mathrm{E}-04$ & $1.18 \mathrm{E}-02$ & 4.02E-01 & $3.00 \mathrm{E}-06$ & $3.50 \mathrm{E}-02$ & $2.67 \mathrm{E}+01$ \\
\hline $\begin{array}{l}\text { Cyclophosphamid } 1400 \mathrm{mg} / \mathrm{m}^{2} \text {, i.v. day 1, Doxorubicin } \\
32.5 \mathrm{mg} / \mathrm{m}^{2} / \mathrm{d} \text { d1-2, Vincristine } 2 \mathrm{mg} \text { d1 (CDh) }\end{array}$ & high CHOEP & $1.11 \mathrm{E}+00$ & $6.35 \mathrm{E}-02$ & 1.94E-01 & 7.26E-01 & 3.37E-01 & 1.77E-04 & 1.37E-02 & $1.10 \mathrm{E}+01$ \\
\hline Etoposide 175 mg/m²/d d1-3 (ETh) & high CHOEP & $1.10 \mathrm{E}+00$ & $6.84 \mathrm{E}-02$ & 2.42E-02 & 4.87E-02 & $6.41 \mathrm{E}-01$ & $8.00 \mathrm{E}-06$ & $3.50 \mathrm{E}-02$ & $7.29 \mathrm{E}+00$ \\
\hline Carboplatin, Paclitaxel 225 mg/m² (CP) & Carboplatin, Paclitaxel & $1.00 \mathrm{E}+00$ & 7.71E-02 & 5.05E-04 & $6.00 E+01$ & $6.00 E+01$ & $2.89 \mathrm{E}-04$ & & \\
\hline Doxorubicin 60 mg/m², Docetaxel 75 mg/m² (TA) & Doxorubicin, Docetaxel & $2.01 E+00$ & 7.24E-02 & $1.39 \mathrm{E}-02$ & $2.28 \mathrm{E}-01$ & $4.22 \mathrm{E}+00$ & $3.20 \mathrm{E}-05$ & & \\
\hline Paclitaxel 225 mg/m², 3-h-Infusion (Pacli or P225) & ETC & $1.05 \mathrm{E}+00$ & 1.73E-02 & $2.46 \mathrm{E}-01$ & $8.21 \mathrm{E}-01$ & $3.50 E+00$ & 7.07E-04 & 1.97E-01 & 2.65E-01 \\
\hline Paclitaxel 175 mg/m² 3-h-Infusion (Pacli or P175) & EC-T & $1.05 E+00$ & $1.73 \mathrm{E}-02$ & 7.00E-05 & $8.21 \mathrm{E}-01$ & $3.50 \mathrm{E}+00$ & 7.01E-04 & 1.97E-01 & 2.65E-01 \\
\hline Cyclophosphamid 600 mg/m², 24-h-Infusion (Cyclo or C600) & EC-T & $1.01 E+00$ & $6.40 \mathrm{E}-02$ & 1.99E-01 & 7.43E-01 & 1.15E-01 & $1.40 \mathrm{E}-04$ & $2.50 \mathrm{E}-02$ & $8.99 \mathrm{E}+00$ \\
\hline Cyclophosphamid 2500 mg/m², 24-h-Infusion (Cyclo or C2500) & ETC & $1.01 E+00$ & $6.40 \mathrm{E}-02$ & 1.99E-01 & $7.58 \mathrm{E}-01$ & $1.27 \mathrm{E}-01$ & $1.43 \mathrm{E}-04$ & $2.50 \mathrm{E}-02$ & $1.31 \mathrm{E}+01$ \\
\hline Epirubicin 90 mg/m² 3-h-Infusion (Epi or E90) & EC-T & $1.99 E+00$ & $4.48 \mathrm{E}-02$ & $1.80 \mathrm{E}-05$ & $5.51 \mathrm{E}-02$ & $1.80 \mathrm{E}-01$ & $5.18 \mathrm{E}-04$ & 2.42E-02 & $3.96 \mathrm{E}+00$ \\
\hline Epirubicin 150 mg/m² 3-h-Infusion (Epi or E150) & ETC & $1.99 \mathrm{E}+00$ & 4.48E-02 & $2.53 \mathrm{E}-03$ & $1.56 \mathrm{E}+00$ & $6.62 \mathrm{E}+00$ & $1.58 \mathrm{E}-02$ & $2.42 \mathrm{E}-02$ & $3.01 E+01$ \\
\hline Cytarabine 2000 mg/m² (Cyta) & ESHAP & $1.00 \mathrm{E}+00$ & $1.31 \mathrm{E}-01$ & 4.64E-01 & $8.80 \mathrm{E}-03$ & $8.84 \mathrm{E}-03$ & $2.32 \mathrm{E}-03$ & & \\
\hline Cisplatin 25 mg/m²/d (Cisp) & ESHAP & $1.00 \mathrm{E}+00$ & $6.32 \mathrm{E}-02$ & $3.24 \mathrm{E}-02$ & 1.93E-01 & $9.60 \mathrm{E}-03$ & 4.10E-04 & & \\
\hline Etoposide 40 mg/m² (ET40) & ESHAP & $1.10 \mathrm{E}+00$ & $6.84 \mathrm{E}-02$ & $0.00 \mathrm{E}+00$ & $1.62 \mathrm{E}-02$ & 8.65E-02 & 2.00E-06 & & \\
\hline
\end{tabular}

Parameters also depend on drug doses and age ( $\leq 60$ vs. $>60$ years). 
schedules are modeled (scenarios 18, 26-29). If applicable, toxicity estimates of drugs or drug combinations established in the previous section were kept constant. Comparisons of model and data for selected scenarios can be found in Figure 5. All other scenarios can be found in the appendix (Additional file 1: Figures A9-A10).

\section{Quantification of chemotherapy toxicity}

As can be seen from Figures 4 and 5 and those of other scenarios presented in the appendix, our model assumptions regarding chemotherapy action and corresponding toxicity parameters resulted in a reasonable fit of almost all scenarios considered.

Our toxicity parameters can be interpreted as the strength of chemotherapy damage on the respective cell stage. We now discuss and interprete these parameters in more detail. An overview for different drugs and drug doses can be found in Table 3.

Sensitivity analysis (Additional file 1: Figures A1, A2) revealed that among bone marrow toxicities, those estimated for stem cells showed the highest precision in most scenarios. The LY toxicity and the delay parameters are sensitive too.

Figure 6 shows the relation between stem cell toxicity and resulting WBC toxicity. The correlation (Spearman) is 0.88 , i.e. the stem cell toxicity is a good predictor of the overall toxicity. Additional file 1: Figure A11 of the supplement material shows the correlation of MGB $\mathrm{AOC}$ and WBC AOC. In Additional file 1: Figure A12 the correlation of ANC AOC and WBC AOC is depicted. Both are highly correlated too (MGB AOC vs. WBC AOC $\mathrm{r}=0.94$, ANC AOC vs. WBC AOC $\mathrm{r}=0.92$ ).

For Cyclophosphamide (with or without Doxorubicin and Vincristin) we estimated a high stem cell toxicity in agreement with the literature (e.g. [52]). For Etoposide, we obtained a rather low stem cell toxicity, even for increased dose levels, and higher toxicity to later cell stages. This also complies with the literature (e.g. [2]). Due to the rather small haematotoxic influence of Vincristine, we abstained from determining a separate parameter set for Vincristine [52].

Two anthracyclines were considered, Doxorubicine and Epirubicine. The first one was always applied in combination with other drugs, namely with Cyclophsphamide for therapies of lymphoma diseases and with Docetaxel for the TA regimen as adjuvant breast cancer therapy. Therefore, no separate parameter set of Doxorubicine alone could be derived. In contrast, Epirubicine was applied as single drug in the ETC therapy of breast cancer patients. This allows us to derive a separate set
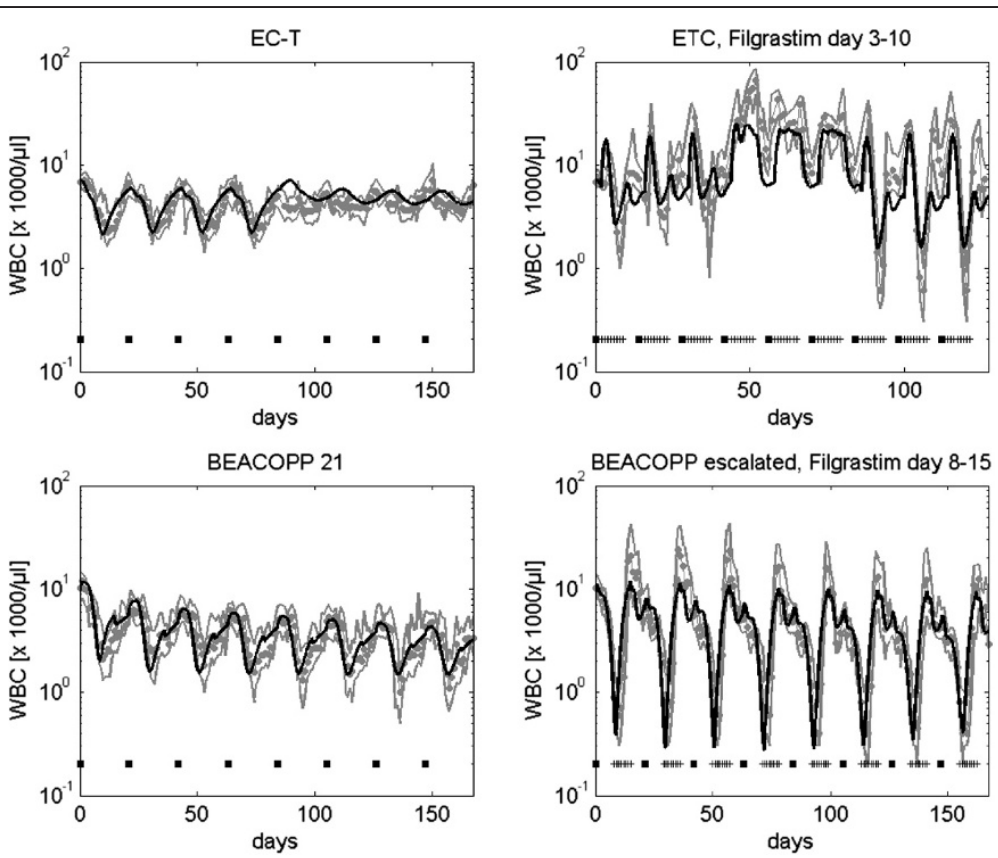

Figure 5 Simulation results of selected complex chemotherapies. We present results for the two breast cancer therapies, EC-T and ETC with Filgrastim on days 3-10 (first row). Note that in these schedules, chemotherapeutic drugs differ between cycles: For EC-T the drugs epirubicine and cyclophosphamide where applied in combination in the first four cycles. The single drug paclitaxel was applied for the last four cycles. For ETC, the single drug epirubicine was applied in three cycles followed by three cycles of paclitaxel and three cycles of cyclophosphamide. We also present two therapies of advanced Hodgkin's lymphoma, BEACOPP-21 and BEACOPP escalated with Filgrastim on days 8-15, in which multiple drugs are administered at different time points per cycle (second row). Dosages can be found in Table 1. Dots represent patient medians, grey lines represent interquartile range of patient data, squares represent chemotherapy administrations, " + " denote G-CSF-injections. 


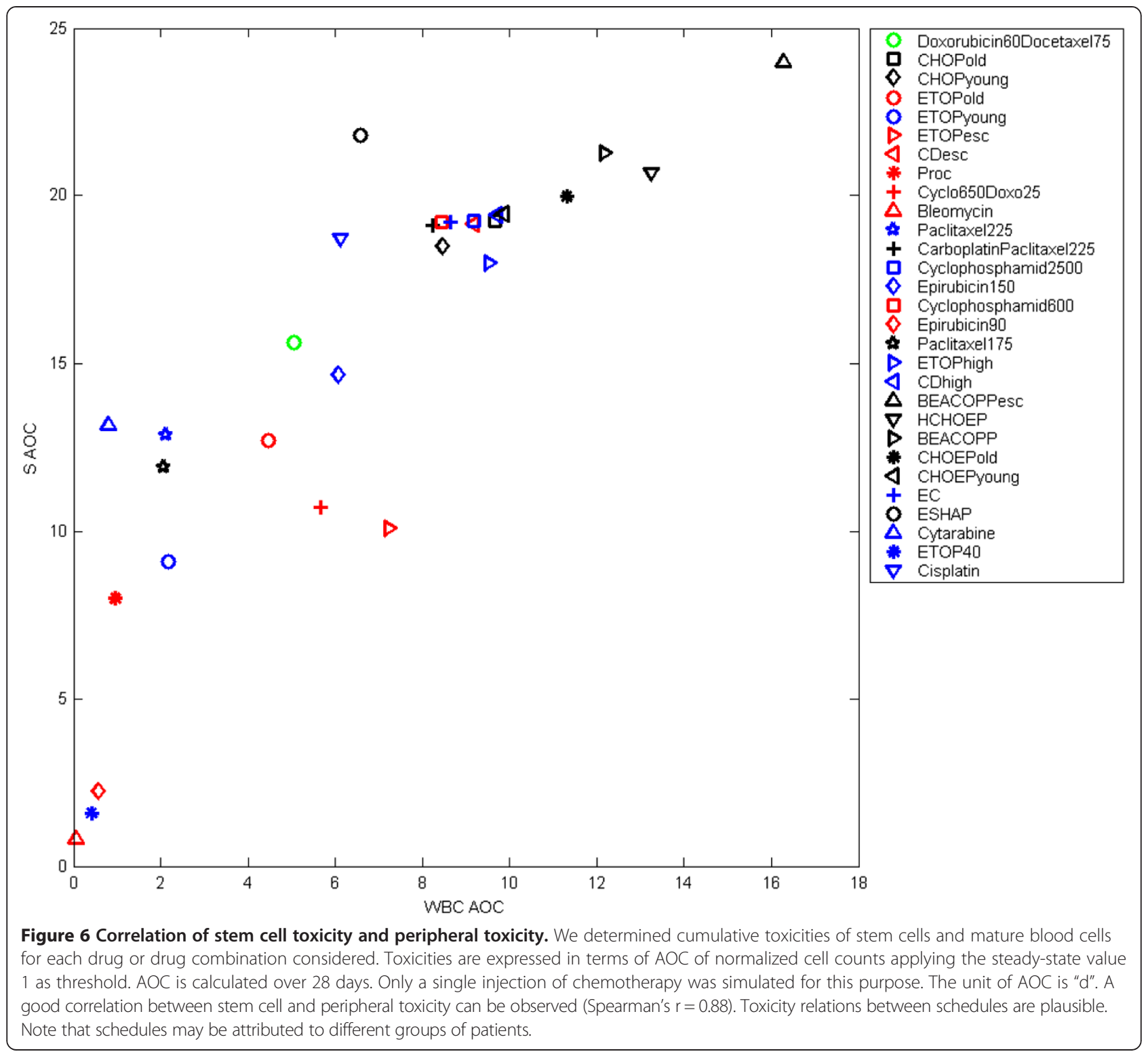

of toxicity parameters for two dose levels of Epirubicine (90 and $150 \mathrm{mg} / \mathrm{m}^{2}$ ) showing a considerable, dosedependend stem cell toxicity in agreement with the literature [52].

According to our assumption 5, cytotoxic drugs are assumed to contribute to overall toxicity independently of each other. This does not apply for the combination of Carboplatin and Paclitaxel for which it is known that the combination is less toxic than the single drugs [53]. Therefore, a new set of toxicity parameters was determined for this drug combination, which indeed resulted in lower estimates than for Paclitaxel alone (see Table 3).

We assumed that risk groups of haematotoxicity can be traced back to differences in toxicity parameters (assumption 7). This assumption worked fine if comparing the toxicity outcomes of young and elderly patients treated with $\mathrm{CHOP}$ or CHOEP chemotherapies. For both risk groups the agreement of model and data is fine while corresponding toxicity parameters are higher in elderly patients.

\section{Validation}

Data sets not used for parameter fitting served as validation scenarios of our model. This requires that the corresponding chemotherapy parameters were determined on the basis of other data sets. Scenarios 12, 22, 32 fulfill these requirements. Figure 7 shows the agreement of model and data for validation scenarios.

\section{Model predictions}

A key feature of our model is that it allows simulations of alternative G-CSF schedules and its effects on overall 

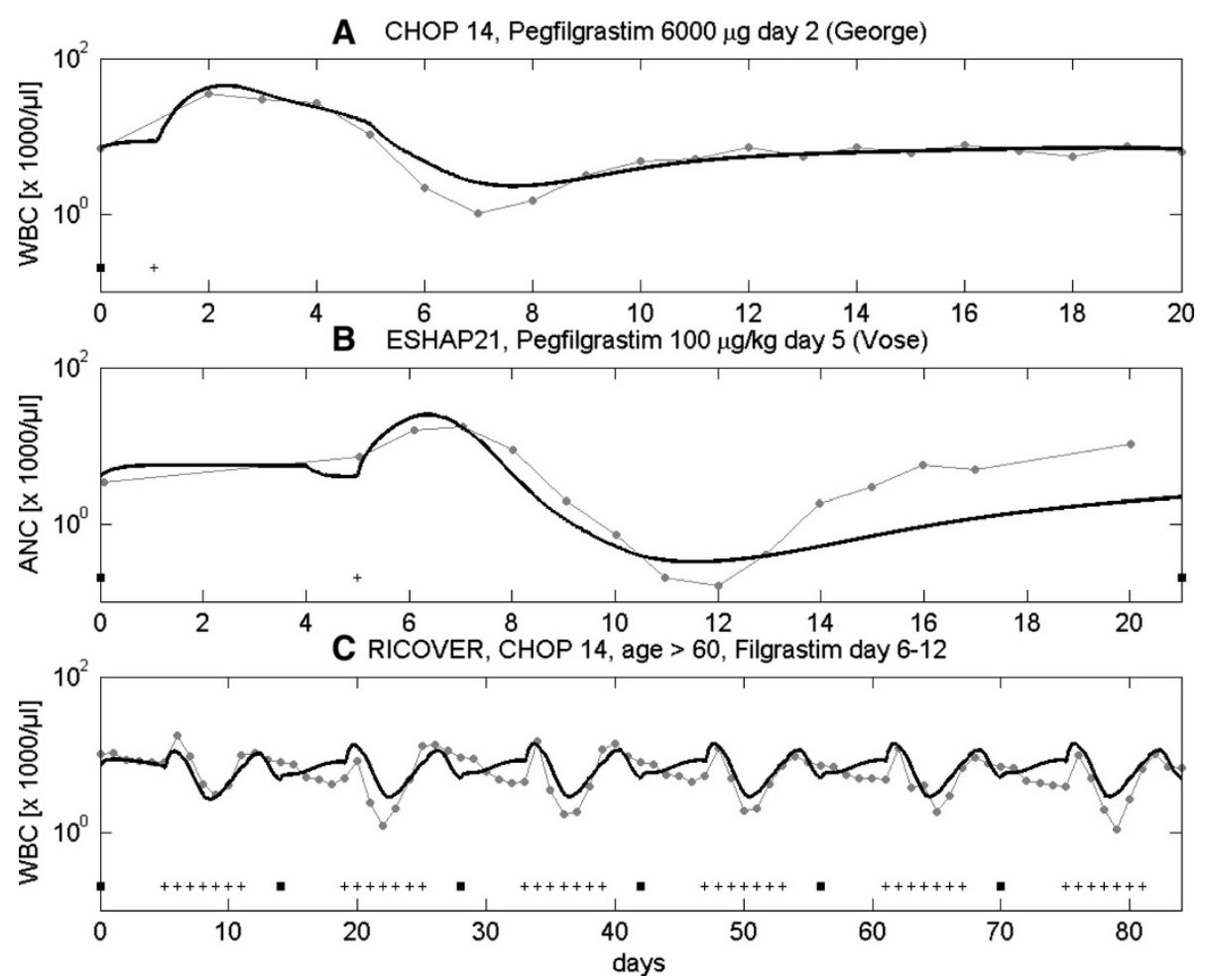

Figure 7 Validation scenarios. We compare model results with clinical data from validation scenarios: A: CHOP with Pegfilgrastim $6000 \mu \mathrm{g}$ on day 2 (data: [37]), B: ESHAP with Pegfilgrastim on day 5 (data: [45]), C: CHOP with 480 mg Filgrastim on cycle-days 6-12, for elderly patients, data: [43]. Dots represent patient medians, squares represent the chemotherapy administrations, + are time points with G-CSF-injections.

leukotoxicity. We demonstrate this on the basis of the CHOP regimen for elderly patients: Using toxicity parameters estimated for CHOP based on the G-CSF schedules presented above, we modified the starting time and the duration of Filgrastim treatment. Comparisons of schedules can be performed by calculating the AOC of the simulation results. Two examples of simulated G-CSF schedules are presented in Figure 8. The regimen day 2-8 results in clearly inferior AOC than the current standard (G-CSF at day 3-12). In contrast, for the schedule day 5-13 we predict a better AOC than the current standard even though the number of injections is reduced.

We calculated the WBC AOC for 6 cycles of the CHOP-14 regimen, administered to elderly patients, in dependence on different Filgrastim doses and injection numbers starting on day seven (Figure 9). Best results are predicted, if Filgrastim injections are applied from day seven up to the end of the therapy cycle (see also [54]). Increasing G-CSF dose results only in marginal improvements.

\section{Discussion}

Conventional cytotoxic chemotherapy plays a major role in cancer therapy. Development of intensified regimen improved the outcome of several diseases $[39-41,55,56]$ but is limited by toxic side effects. A major, frequently dose-limiting side effect is granulotoxicity which is routinely treated with the growth factor G-CSF. A variety of pharmaceutical derivatives are available, which differ greatly in pharmacokinetic and -dynamic properties. Furthermore, outcome of growth factor treatment depends on many factors such as chemotherapy drugs used, drug doses, growth-factor derivatives and individual risk factors $[57,58]$. Due to this variety of variable therapy parameters, identification of optimal growthfactor schedules cannot be performed solely on the basis of clinical trials.

We recently developed a model of the pharmacokinetic and -dynamic action of the G-CSF derivatives Filgrastim and Pegfilgrastim under conventional polychemotherapy [25]. We also showed that the model successfully predicts the outcome of alternative G-CSF schedules [54]. However, so far only a single simple chemotherapy schedule was considered for which the data base was most comprehensive, namely the $\mathrm{CHOP}$ regimen used to treat high-grade non-Hodgkin's lymphoma diseases. The major purpose of the present work is to extend the applicability of our model considering a broad range of conventional chemotherapy schedules. This requires the construction of a comprehensive model of chemotherapy action on the granulopoietic system. 


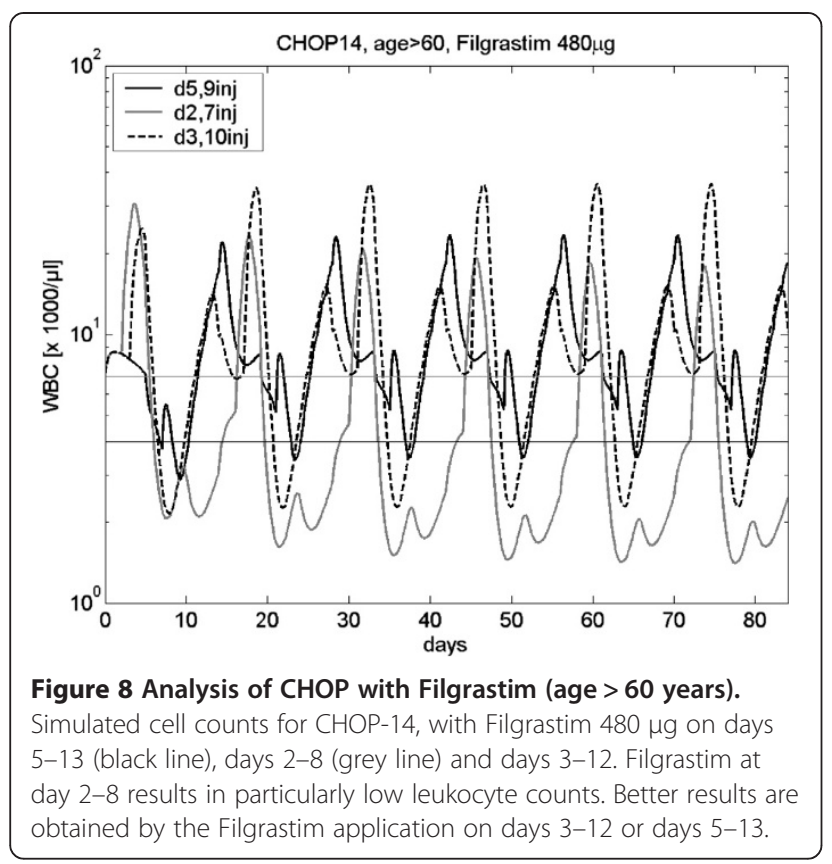

Making a number of biologically plausible assumptions and translating them into differential equations allowed us to predict granulocyte and leukocyte dynamics of virtually all chemotherapy scenarios with published time series data of granulocytes and leukocytes (33 scenarios comprising 10 different chemotherapies). Modelling of chemotherapies essentially requires estimation of dose, drug and cell-stage specific toxicity parameters. In consequence, our model can easily be applied to novel chemotherapy scenarios for which time series data are available allowing estimation of these parameters. We showed how the model can be used to systematically explore the outcomes of alternative G-CSF schedules for a chemotherapy for which toxicity parameters are available.

Ongoing efforts to model haematopoiesis under chemotherapy and growth-factor applications are considerable [59-84]. Most newer models consider G-CSF as the major stimulant of granulopoiesis, and account for corresponding intracellular mechanisms, as well as for receptor binding kinetics and endocytic ligand depletion $[62,64,85,86]$. Shochat et al. [63], and Foley et al. [59], proposed models considering both, stimulating effects of G-CSF as well as the cell depleting effects of chemotherapy. However, published models usually consider selected chemotherapy regimens. So far it has not been shown that these model concepts are valid for a broad range of chemotherapies and schedules $[59,63]$. First attempts to predict the performance of alternative G-CSF schedules on the basis of these models were performed [87].

In order to construct a comprehensive model of chemotherapy action on granulopoiesis, we made the following assumptions and translated them into differential equations:

\section{Delayed toxicity}

It is assumed that the cell depleting effect of chemotherapy starts immediately after drug application. The

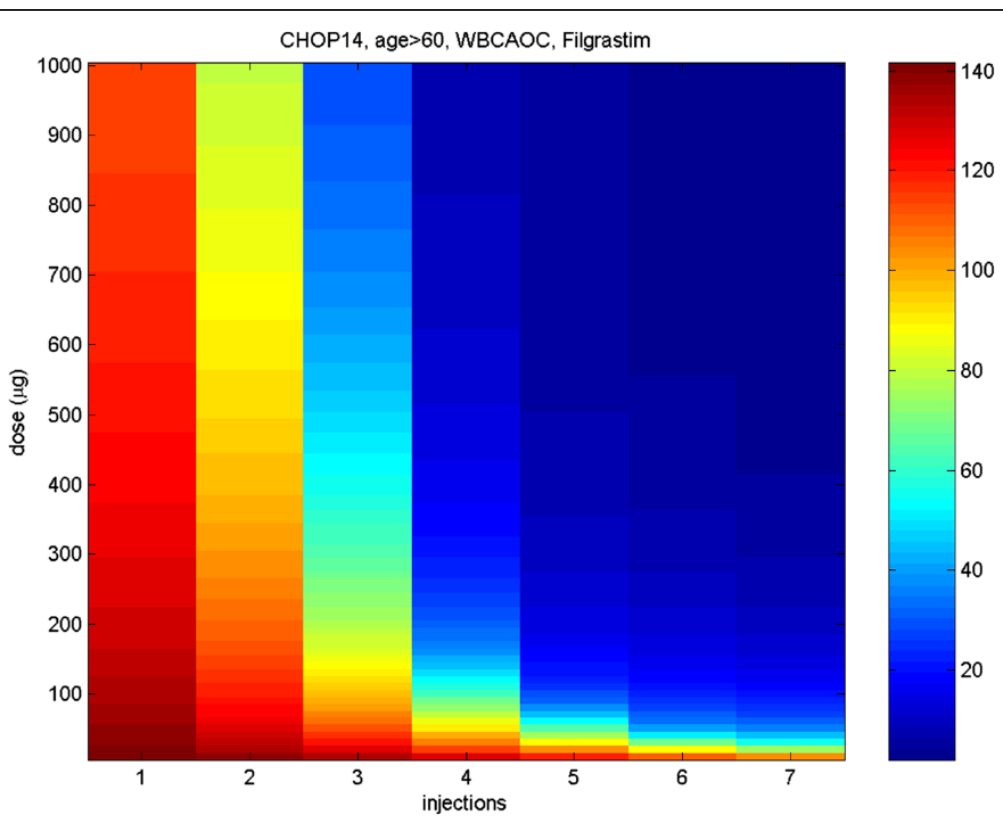

Figure 9 Modified Filgrastim schedules for CHOP-14 in elderly patients. Predicted WBC AOC (applying a threshold of 4000/ $\mu$, calculated over 84 days, unit of AOC is $1000 / \mu^{*} d$ ) under CHOP-14 with Filgrastim: G-CSF injections start at day 7 in each cycle. We modified the number of Filgrastim injections and its doses. The color scale on the right corresponds to AOC values. 
maximum is reached after some time delay. This assumption is motivated by available time series data of murine bone marrow cellularity after a variety of cytotoxic drug applications often showing a maximum response to chemotherapy treatment at later time points even if the underlying drugs are quickly metabolized in vivo [52]. This phenomenon can be explained for example by delayed apoptosis of cells after damage, e.g. at time when cells entering their next cell cycle.

\section{Cell type specific toxicity}

It is assumed that chemotherapy acts cell type specific which is supported by numerous experimental data [52]. This implies that toxicity parameters are assumed to be dose, drug and cell-stage specific. Most of our data sets comprise leukocyte counts instead of neutrophil profiles. To account for this fact, we accompanied our cell-kinetic model of granulopoiesis by a simple model of lymphotoxicity. This is motivated by differing dynamics of granulocytes and lymphocytes observed in chemotherapy-treated mice [88]. Further clinical evidence is provided by a trial with breast cancer patients undergoing polychemotherapy. In this study, suppressed B- and T-cell populations were still present at times when the absolute neutrophil count had returned to normal or even higher than normal values [89]. These findings are in good agreement with the results of our parameter estimation (prolonged toxicity for lymphocytes). However, to precisely quantify lymphocyte toxicity profiles, more detailed differential blood counts of patients undergoing chemotherapy would be required than currently available.

\section{First cycle effect}

There is some evidence that the first application of chemotherapeutic drugs results in higher toxicity [81,90-92]. We modelled this effect in a phenomenologic way by multiplying toxicity parameters with a factor $\geq 1$ at time of first application of chemotherapy.

\section{Toxicity of drug combinations}

To estimate the overall toxicity of a drug combination, we achieved satisfying results by adding the toxicity parameters of single substances or groups of substances. However, there is evidence that some drug combinations interact in a paradoxical way, resulting in an overall toxicity that is smaller than the toxicity of either one of the single agents. For example, thrombocytopenia tends to be significantly less pronounced in patients treated with carboplatin when combined with paclitaxel (which by itself causes thrombocytopenia, too) $[53,93,94]$. The reason for the platelet sparing effect of this combination is still unknown. Therefore, it is possible that the toxicity of a drug combination cannot be simply derived by adding the toxicity parameters of their components determined in previous studies. In these cases, new parameter fittings are required.

\section{Action of chemotherapy on granulopoiesis}

We modeled chemotherapy to act cytotoxic, rather than cytostatic. As result, cells in our model were removed from the compartments directly, whereas cell kinetic properties (amplification and transit time) are not affected. However, it is well known that many drugs act cytostatically, for example by disrupting cellular metabolism or DNA synthesis. Hence, onset and severity of chemotherapy associated myelotoxicity depend on the cell cycle. However, in our modeling framework, it is neither possible nor necessary to distinguish between cytostatic and cytotoxic effects since both result in reduced cell numbers within a relatively small time frame. Closely meshed time series data of bone marrow cell stages would be required for a more detailed modelling of this issue which however cannot be established for humans.

\section{Modelling risk groups}

Numerous clinical risk factors regarding toxic response of patients are known such as age, sex and general health status [49]. We hypothesize that this heterogeneity can be traced back to different sets of toxicity parameters rather than cell kinetic parameters of granulopoiesis [28,95]. This assumption allowed us for example to stratify patients into risk groups described by risk-specific toxicity parameters [58]. So far, differences between younger and elderly patients could be successfully explained by higher toxicity parameters as can be seen on our toxicity parameters for etoposide and the combination of cyclophosphamide, doxorubicine and vincristine applied in CHOP-like chemotherapy regimens. For both risk groups, corresponding parameter estimates resulted in good explanation of clinical data.

Overall, our model assumptions proved to be feasible for modelling almost all published time series data after a large variety of chemotherapies and schedules.

A few scenarios, for which complete sets of toxicity parameters are available, were used to successfully validate the model. We qualitatively compared derived toxicity parameters between schedules and received clinically plausible results: We estimated for example that Bleomycin $\left(10 \mathrm{mg} / \mathrm{m}^{2}\right)$, Procarbacine $\left(100 \mathrm{mg} / \mathrm{m}^{2}\right)$ and low dose Etoposide $\left(100 \mathrm{mg} / \mathrm{m}^{2}\right)$ have low granulotoxicity according to clinical experiences. In contrast, BEACOPP escalated and high-CHOEP are among the most toxic therapies in agreement with high percentages of grade 3 and 4 leucopoenia observed in these patients $[43,49]$.

We observed that stem cell toxicities of drugs or drug combinations correlate well with resulting leukocyte 
toxicity $(\mathrm{r}=0.88$, Figure 6$)$ indicating that the parameter of stem cell toxicity is the most sensitive of our parameters characterizing chemotherapy toxicity. In contrast, the parameters for CG, PGB and MGB are less well characterized, in general. For these three cell stages, we have to acknowledge that higher toxicity at later stages can somewhat be compensated with lower toxicity at earlier cell stages and vice versa.

Finally, we demonstrated how the model could be used to make clinically relevant predictions regarding the outcome of alternative growth-factor schedules after chemotherapy. This requires that the toxicity parameters of the considered therapy are available. Then, the model can be used to simulate and compare alternative growth-factor schedules. Since hard clinical endpoints such as febrile neutropenia, use of antibiotics or length of stay in hospital cannot be addressed by our modelling, it was necessary to use surrogate markers in order to compare efficacy of G-CSF prophylaxis between schedules. We used the area between model curve and the line of $2.000 / \mu \mathrm{l}$ neutrophils or $4.000 / \mu \mathrm{l}$ leukocytes for this purpose. Other measures of relative toxicity are discussed elsewhere [95].

Finally, we have to acknowledge that the present model only allows median predictions while critical time-courses are clinically more relevant and therapy-limiting. Although this aspect is not yet covered, there is a clear perspective towards modelling individual data either by fitting parameter sets for patient risk groups or by assuming distributions of model parameters. Accordingly, we plan to extend our model and apply it in order to support improvement and individualisation of G-CSF therapies. Since we have the clear intention to apply our model in clinical contexts, we also plan public release of our model software in the near future.

\section{Conclusion}

We successfully developed a bio-mathematical model of granulopiesis under chemotherapy and applications of the G-CSF derivatives Filgrastim and Pegfilgrastim. Our model is able to simulate neutrophil and leukocyte profiles in the peripheral blood under various chemotherapies, with and without Filgrastim or Pegfilgrastim. The model consistently explains available clinical data, and can be used to predict the performance of alternative G-CSF schedules.

\section{Additional file}

Additional file 1: Modelling chemotherapy effects on

granulopoiesis: Supplement Material. The file GraPaper-2-Appendix.pdf contains sensitivity analysis and further simulation results.

\section{Competing interests}

The authors declare that they have no competing interests.

\section{Authors' contributions}

Developed the model: SS, CE, MS. Conceived and designed model simulations: SS, MS. Performed model simulations: SS. Wrote the article: SS, MS. Contributed to paper writing: CE. Contributed to discussion: ML. Final approval of manuscript: all authors.

\section{Acknowledgements}

This research was supported by the BMBF-grant on Medical Systems Biology "HaematoSys" (BMBF-FKZ 0315452). We further thank the German Hodgkin's Lymphoma Study Group (Volker Diehl, chairman), the German High-Grade Non-Hodgkin's Lymphoma Study Group (Michael Pfreundschuh, chairman) and the German Breast Group (Gunther von Minckwitz, chairman) for kind permission to use clinical trial data.

SS, MS were funded by the Leipzig Interdisciplinary Research Cluster of Genetic Factors, Clinical Phenotypes and Environment (LIFE Center, Universität Leipzig). LIFE is funded by means of the European Union, by the European Regional Development Fund (ERFD), the European Social Fund and by means of the Free State of Saxony within the framework of the excellence initiative.

We acknowledge support from the German Research Foundation (DFG) and Leipzig University within the program of Open Access Publishing.

Received: 2 September 2014 Accepted: 11 December 2014

Published online: 24 December 2014

\section{References}

1. Bonadonna G, Valagussa P, Moliterni A, Zambetti M, Brambilla C: Adjuvant cyclophosphamide, methotrexate, and fluorouracil in node-positive breast cancer: the results of 20 years of follow-up. N Engl J Med 1995, 332(14):901-906.

2. Budman DRBD, Cirrincione $C T$, Henderson IC, Wood WC, Weiss RB, Ferree CR, Muss HB, Green MR, Norton L, Frei E 3rd: Dose and dose intensity as determinants of outcome in the adjuvant treatment of breast cancer. The Cancer and Leukemia Group B. J Natl Cancer Inst 1998, 90:1205-1211.

3. Kwak LW, Halpern J, Olshen RA, Horning SJ: Prognostic significance of actual dose intensity in diffuse large-cell lymphoma: results of a tree-structured survival analysis. J Clin Oncol 1990, 8(6):963-977.

4. Epelbaum R, Faraggi D, Ben-Arie Y, Ben-Shahar M, Haim N, Ron Y, Robinson E, Cohen Y: Survival of diffuse large cell lymphoma. Cancer 1990, 66(6):1124-1129.

5. Lepage E, Gisselbrecht C, Haioun C, Sebban C, Tilly H, Bosly A, Morel P, Herbrecht R, Reyes F, Coiffier B: Prognostic significance of received relative dose intensity in non-Hodgkin's lymphoma patients: application to LNH-87 protocol. The GELA. (Groupe d'Etude des Lymphomes de I'Adulte). Ann Oncol 1993, 4(8):651-656.

6. Dale DC: Colony-stimulating factors for the management of neutropenia in cancer patients. Drugs 2002, 62(Suppl 1):1-15.

7. Hryniuk W: Dosage parameters in chemotherapy of breast cancer. Breast Dis 2001, 14:21-30.

8. Hryniuk WM, Goodyear M: The calculation of received dose intensity. J Clin Oncol 1990, 8(12):1935-1937.

9. Smith TJ, Khatcheressian J, Lyman GH, Ozer H, Armitage JO, Balducci L, Bennett CL, Cantor SB, Crawford J, Cross SJ, Demetri G, Desch CE, Pizzo PA, Schiffer CA, Schwartzberg L, Somerfield MR, Somlo G, Wade JC, Wade JL, Winn RJ, Wozniak AJ, Wolff AC: 2006 update of recommendations for the use of white blood cell growth factors: An evidence-based clinical practice guideline. J Clin Oncol 2006, 24(19):3187-3205.

10. Gisselbrecht $C$, Haioun C, Lepage E, Bastion Y, Tilly H, Bosly A, Dupriez B, Marit G, Herbrecht R, Deconinck E, Marolleau JP, Yver A, Dabouz-Harrouche F, Coiffier B, Reyes F: Placebo-controlled phase III study of lenograstim (glycosylated recombinant human granulocyte colony-stimulating factor) in aggressive non-Hodgkin's lymphoma: factors influencing chemotherapy administration. Groupe d'Etude des Lymphomes de I'Adulte. Leuk Lymphoma 1997, 25(3-4):289-300.

11. Sonneveld $P$, de Ridder $M$, van der Lelie $H$, Nieuwenhuis $K$, Schouten $H$, Mulder A, van Reijswoud I, Hop W, Lowenberg B: Comparison of doxorubicin and mitoxantrone in the treatment of elderly patients with advanced diffuse non-Hodgkin's lymphoma using CHOP versus CNOP chemotherapy. J Clin Oncol 1995, 13:2530-2539.

12. Tirelli U: CHOP is the standard regimen in patients $>$ or $=70$ years of age with intermediate-grade and high-grade non-Hodgkin's lymphoma: results of a randomized study of the European Organization for Research 
and Treatment of Cancer Lymphoma Cooperative Study Group. J Clin Oncol 1998, 16:27-34.

13. Osby E, Hagberg H, Kvaløy S, Teerenhovi L, Anderson H, Cavallin-Stahl E, Holte $H$, Myhre J, Pertovaara H, Björkholm M: CHOP is superior to CNOP in elderly patients with aggressive lymphoma while outcome is unaffected by filgrastim treatment: results of a Nordic Lymphoma Group randomized trial. Blood 2003, 101:3840-3848.

14. Meyer RM, Browman GP, Samosh ML, Benger AM, Bryant-Lukosius D, Wilson WE, Frank GL, Leber BF, Sternbach MS, Foster GA: Randomized phase II comparison of standard CHOP with weekly CHOP in elderly patients with non-Hodgkin's lymphoma. J Clin Oncol 1995, 13(9):2386-2393.

15. Marangolo M, Bengala C, Conte PF, Danova M, Pronzato P, Rosti G, Sagrada $P$ : Dose and outcome: the hurdle of neutropenia (Review). Oncol Rep 2006, 16(2):233-248.

16. Briones MA, Josephson CD, Hillyer CD: Granulocyte transfusion: revisited. Curr Hematol Rep 2003, 2(6):522-527.

17. Dale D: Current management of chemotherapy-induced neutropenia: the role of colony-stimulating factors. Semin Oncol 2003, 30(4 Suppl 13):3-9.

18. Mitchell PL, Morland B, Stevens MC, Dick G, Easlea D, Meyer LC, Pinkerton CR: Granulocyte colony-stimulating factor in established febrile neutropenia: a randomized study of pediatric patients. J Clin Oncol 1997, 15(3):1163-1170.

19. Lyman $\mathrm{GH}$, Kuderer NM: Filgrastim in patients with neutropenia: potential effects on quality of life. Drugs 2002, 62(Suppl 1):65-78.

20. Garcia-Carbonero R, Mayordomo Jl, Tornamira MV, Lopez-Brea M, Rueda A, Guillem V, Arcediano A, Yubero A, Ribera F, Gomez C, Trés A, Pérez-Gracia $J$, Lumbreras C, Hornedo J, Cortés-Funes H, Paz-Ares L: Granulocyte colony-stimulating factor in the treatment of high-risk febrile neutropenia: a multicenter randomized trial. J Natl Cancer Inst 2001, 93(1):31-38.

21. Maher DW, Lieschke GJ, Green M, Bishop J, Stuart-Harris R, Wolf M, Sheridan WP, Kefford RF, Cebon J, Olver I, McKendrick J, Toner G, Bradstock K, Lieschke M, Cruickshank S, Tomita DK, Hoffman EW, Fox RM, Morstyn G: Filgrastim in patients with chemotherapy-induced febrile neutropenia. A double-blind, placebo-controlled trial. Ann Intern Med 1994, 121(7):492-501.

22. Siena S, Secondino S, Giannetta L, Carminati O, Pedrazzoli P: Optimising management of neutropenia and anaemia in cancer chemotherapy-advances in cytokine therapy. Crit Rev Oncol Hematol 2003, 48(Suppl):S39-47.

23. Schmitz S, Franke H, Brusis J, Wichmann HE: Quantification of the Cell Kinetic Effects of G-Csf Using a Model of Human Granulopoiesis. Exp Hematol 1993, 21(6):755-760.

24. Lord BI, Bronchud MH, Owens S, Chang J, Howell A, Souza L, Dexter TM: The kinetics of human granulopoiesis following treatment with granulocyte colony-stimulating factor in vivo. Proc Natl Acad Sci U S A 1989, 86(23):9499-9503.

25. Scholz M, Schirm S, Wetzler M, Engel C, Loeffler M: Pharmacokinetic and -dynamic modelling of G-CSF derivatives in humans. Theor Biol Med Model 2012, 9:32.

26. Wetzler M: Mathematisches Kompartimentmodell der menschlichen Granulopoese zur Beschreibung der pharmakokinetischen und pharmakodynamischen Eigenschaften der G-CSF-Derivate Filgrastim und Pegfilgrastim unter Chemotherapie. Leipzig: Leipzig; 2012.

27. Schirm S, Engel C, Loeffler M, Scholz M: A biomathematical model of human erythropoiesis under erythropoietin and chemotherapy administration. PLoS One 2013, 8(6):e65630.

28. Chatta GS, Price TH, Allen RC, Dale DC: Effects of in vivo recombinant methionyl human granulocyte colony-stimulating factor on the neutrophil response and peripheral blood colony-forming cells in healthy young and elderly adult volunteers. Blood 1994, 84(9):2923-2929.

29. Bishop CR, Athens JW, Boggs DR, Warner HR, Cartwright GE, Wintrobe MM: Leukokinetic studies. 13. A non-steady-state kinetic evaluation of the mechanism of cortisone-induced granulocytosis. J Clin Invest 1968, 47(2):249-260.

30. Dale DC, Fauci AS, Wolff SM: Alternate-day prednisone. Leukocyte kinetics and susceptibility to infections. N Engl J Med 1974, 291(22):1154-1158.

31. Karle $H$, Hansen NE: Neutrophil kinetics in corticosteroid induced neutrophilia measured by plasma lysozyme. Scand J Haematol 1975, 14(3):190-195.

32. Holmes FA, Jones SE, O'Shaughnessy J, Vukelja S, George T, Savin M, Richards D, Glaspy J, Meza L, Cohen G, Dhami M, Budman DR, Hackett J, Brassard M, Yang $B B$, Liang BC: Comparable efficacy and safety profiles of once-per-cycle pegfilgrastim and daily injection filgrastim in chemotherapy-induced neutropenia: a multicenter dose-finding study in women with breast cancer. Ann Oncol 2002, 13(6):903-909.
33. Johnston E, Crawford J, Blackwell S, Bjurstrom T, Lockbaum P, Roskos L, Yang BB, Gardner S, Miller-Messana MA, Shoemaker D, Garst J, Schwab G: Randomized, dose-escalation study of SD/01 compared with daily filgrastim in patients receiving chemotherapy. J Clin Oncol 2000, 18(13):2522-2528.

34. Trumper L, Zwick C, Ziepert M, Hohloch K, Schmits R, Mohren M, Liersch R, Bentz M, Graeven U, Wruck U, Hoffmann M, Metzner B, Hasenclever D, Loeffler $M$, Pfreundschuh M: Dose-escalated CHOEP for the treatment of young patients with aggressive non-Hodgkin's lymphoma: I. A randomized dose escalation and feasibility study with bi- and tri-weekly regimens. Ann Oncol 2008, 19(3):538-544.

35. Zamboni WC: Pharmacokinetics of pegfilgrastim. Pharmacotherapy 2003, 23(8 Pt 2):9S-14S.

36. Yowell SL, Blackwell S: Novel effects with polyethylene glycol modified pharmaceuticals. Cancer Treat Rev 2002, 28:3-6.

37. George S, Yunus F, Case D, Yang BB, Hackett J, Shogan JE, Meza LA, Neumann TA, Liang BC: Fixed-dose pegfilgrastim is safe and allows neutrophil recovery in patients with non-Hodgkin's lymphoma. Leuk Lymphoma 2003, 44(10):1691-1696.

38. Mey UJ, Maier A, Schmidt-Wolf IG, Ziske C, Forstbauer H, Banat GA, Reber M, Strehl JW, Gorschlueter M: Pegfilgrastim as hematopoietic support for dose-dense chemoimmunotherapy with R-CHOP-14 as first-line therapy in elderly patients with diffuse large B cell lymphoma. Support Care Cancer 2007, 15(7):877-884

39. Pfreundschuh $M$, Trumper $L$, Kloess $M$, Schmits R, Feller AC, Rudolph $C$, Reiser M, Hossfeld DK, Metzner B, Hasenclever D, Schmitz N, Glass B, Rübe C, Loeffler M: Two-weekly or 3-weekly CHOP chemotherapy with or without etoposide for the treatment of young patients with good-prognosis (normal LDH) aggressive lymphomas: results of the NHL-B1 trial of the DSHNHL. Blood 2004, 104(3):626-633.

40. Pfreundschuh M, Trumper L, Kloess M, Schmits R, Feller AC, Rube C, Rudolph C, Reiser M, Hossfeld DK, Eimermacher H, Hasenclever D, Schmitz N, Loeffler M: Two-weekly or 3-weekly CHOP chemotherapy with or without etoposide for the treatment of elderly patients with aggressive lymphomas: results of the NHL-B2 trial of the DSHNHL. Blood 2004, 104(3):634-641.

41. DiehI V, Franklin J, Pfreundschuh M, Lathan B, Paulus U, Hasenclever D, Tesch H, Herrmann R, Dörken B, Müller-Hermelink HK, Dühmke E, Loeffler M: Standard and increased-dose BEACOPP chemotherapy compared with COPP-ABVD for advanced Hodgkin's disease. New Engl J Med 2003, 348(24):2386-2395.

42. Möbus VJC, Lück HJ: Intense dose-dense sequential chemotherapy with epirubicin, paclitaxel and cyclophosphamide compared with conventionally scheduled chemotherapy in high-risk primary breast cancer (4+ LN): mature results of an AGO-phase-III study. J Clin Oncol 2010, 28:2874-2880.

43. Pfreundschuh $M$, Schubert J, Ziepert $M$, Schmits $R$, Mohren $M$, Lengfelder $E_{\text {, }}$ Reiser M, Nickenig C, Clemens M, Peter N, Bokemeyer C, Eimermacher $\mathrm{H}, \mathrm{Ho}$ A, Hoffmann M, Mertelsmann R, Trümper L, Balleisen L, Liersch R, Metzner B, Hartmann F, Glass B, Poeschel V, Schmitz N, Ruebe C, Feller AC, Loeffler M: Six versus eight cycles of bi-weekly CHOP-14 with or without rituximab in elderly patients with aggressive CD20+ B-cell lymphomas: a randomised controlled trial (RICOVER-60). Lancet Oncol 2008, 9(2):105-116.

44. Sieber M, Bredenfeld $H$, Josting A, Reineke T, Rueffer U, Koch T, Naumann R, Boissevain F, Koch P, Worst P, Soekler M, Eich H, Müller-Hermelink HK, Franklin J, Paulus U, Wolf J, Engert A, Diehl V: 14-day variant of the bleomycin, etoposide, doxorubicin, cyclophosphamide, vincristine, procarbazine, and prednisone regimen in advanced-stage Hodgkin's lymphoma: Results of a pilot study of the German Hodgkin's Lymphoma Study Group. J Clin Oncol 2003, 21(9):1734-1739.

45. Vose JM, Crump M, Lazarus H, Emmanouilides C, Schenkein D, Moore J, Frankel S, Flinn I, Lovelace W, Hackett J, Liang BC: Randomized, multicenter, open-label study of pegfilgrastim compared with daily filgrastim after chemotherapy for lymphoma. J Clin Oncol 2003, 21(3):514-519.

46. Zwick C, Hartmann F, Zeynalova S, Poschel V, Nickenig C, Reiser M, Lengfelder E, Peter N, Schlimok G, Schubert J, Schmitz N, Loeffler M, Pfreundschuh M: Randomized comparison of pegfilgrastim day 4 versus day 2 for the prevention of chemotherapy-induced leukocytopenia. Ann Oncol 2011, 22(8):1872-1877.

47. Brusamolino E, Rusconi C, Montalbetti L, Gargantini L, Uziel L, Pinotti G, Fava S, Rigacci L, Pagnucco G, Pascutto C, Morra E, Lazzarino M: Dosedense R-CHOP-14 supported by pegfilgrastim in patients with diffuse large B-cell lymphoma: a phase II study of feasibility and toxicity. Haematologica 2006, 91(4):496-502. 
48. Rechenberg I: Evolutionsstrategie 94. Stuttgart: Frommann-Holzboog; 1994.

49. Wunderlich A, Kloess M, Reiser M, Rudolph C, Truemper L, Bittner S, Schmalenberg H, Schmits R, Pfreundschuh M, Loeffler M: Practicability and acute haematological toxicity of 2- and 3-weekly CHOP and CHOEP chemotherapy for aggressive non-Hodgkin's lymphoma: results from the NHL-B trial of the German High-Grade Non-Hodgkin's Lymphoma Study Group (DSHNHL). Ann Oncol 2003, 14(6):881-893.

50. Bodey GP: Infection in cancer patients, A continuing association. Am J Med 1986, 81(1A):11-26.

51. Bodey GP, Buckley M, Sathe YS, Freireic E: Quantitative Relationships between Circulating Leukocytes and Infection in Patients with Acute Leukemia. Ann Intern Med 1966, 328(2):328-340.

52. Lohrmann H-P, Schreml W: Cytotoxic Drugs and the Granulopoietic System. Berlin: Springer; 1982.

53. Guminski A, Harnett $P$, de Fazio A: Carboplatin and paclitaxel interact antagonistically in a megakaryoblast cell line-a potential mechanism for paclitaxel-mediated sparing of carboplatininduced thrombocytopenia. Cancer Chemother Pharmacol 2001, 48(3):229-334.

54. Zeynalova S, Ziepert M, Scholz M, Schirm S, Zwick C, Pfreundschuh M, Loeffler M, German High-Grade Non-Hodgkin Lymphoma Study G: Comparison and modelling of pegylated or unpegylated G-CSF schedules in CHOP-14 regimen of elderly patients with aggressive B-cell lymphoma. Ann Hematol 2013, 92(12):1641-1652.

55. Untch M, Fasching PA, Konecny GE, von Koch F, Conrad U, Fett W, Kurzeder C, Luck HJ, Stickeler E, Urbaczyk H, Liedtke B, Salat C, Harbeck N, Müller V, Schmidt M, Hasmüller S, Lenhard M, Schuster T, Nekljudova V, Lebeau A, Loibl S, von Minckwitz G: PREPARE trial: a randomized phase III trial comparing preoperative, dose-dense, dose-intensified chemotherapy with epirubicin, paclitaxel and CMF versus a standard-dosed epirubicin/cyclophosphamide followed by paclitaxel +/- darbepoetin alfa in primary breast cancer-results at the time of surger. Ann Oncol 2011, 22(9):1988-1998.

56. Untch M, von Minckwitz G, Konecny GE, Conrad U, Fett W, Kurzeder C, Luck HJ, Stickeler E, Urbaczyk H, Liedtke B, Beckmann MW, Salat C, Harbeck N, Müller V, Schmidt M, Hasmüller S, Lenhard M, Nekljudova V, Lebeau A, Loibl S, Fasching PA: PREPARE trial: a randomized phase III trial comparing preoperative, dose-dense, dose-intensified chemotherapy with epirubicin, paclitaxel, and CMF versus a standard-dosed epirubicin-cyclophosphamide followed by paclitaxel with or without darbepoetin alfa in primary breast cancer-outcome on prognosi. Ann Oncol 2011, 22(9):1999-2006.

57. Ziepert M, Hasenclever D, Kuhnt E, Glass B, Schmitz N, Pfreundschuh M, Loeffler M: Standard International prognostic index remains a valid predictor of outcome for patients with aggressive CD20+ B-cell lymphoma in the rituximab era. J Clin Oncol 2010, 28(14):2373-2380.

58. Ziepert M, Schmits R, Trumper L, Pfreundschuh M, Loeffler M, German High-Grade Non-Hodgkin's Lymphoma Study G: Prognostic factors for hematotoxicity of chemotherapy in aggressive non-Hodgkin's lymphoma. Ann Oncol 2008, 19(4):752-762.

59. Foley C, Mackey MC: Mathematical model for G-CSF administration after chemotherapy. J Theor Biol 2009, 257(1):27-44

60. Ostby I, Kvalheim G, Rusten LS, Grottum P: Mathematical modeling of granulocyte reconstitution after high-dose chemotherapy with stem cell support: effect of post-transplant G-CSF treatment. J Theor Biol 2004, 231(1):69-83.

61. Ostby I, Rusten LS, Kvalheim G, Grottum P: A mathematical model for reconstitution of granulopoiesis after high dose chemotherapy with autologous stem cell transplantation. J Math Biol 2003, 47(2):101-136.

62. Roskos LK, Lum P, Lockbaum P, Schwab G, Yang BB: Pharmacokinetic/ pharmacodynamic modeling of pegfilgrastim in healthy subjects. J Clin Pharmacol 2006, 46(7):747-757.

63. Shochat E, Rom-Kedar V, Segel LA: G-CSF control of neutrophils dynamics in the blood. Bull Math Biol 2007, 69(7):2299-2338.

64. Vainstein V, Ginosar Y, Shoham M, Ranmar DO, lanovski A, Agur Z: The complex effect of granulocyte colony-stimulating factor on human granulopoiesis analyzed by a new physiologically-based mathematical model. J Theor Biol 2005, 234(3):311-327.

65. Wang B, Ludden TM, Cheung EN, Schwab GG, Roskos LK: Population pharmacokinetic-pharmacodynamic modeling of filgrastim (r-metHuG-CSF) in healthy volunteers. J Pharmacokinet Pharmacodyn 2001, 28(4):321-342
66. Wichmann HE, Loeffler M, Herkenrath P, Gerhardts MD, Wesselborg C, Wulff H: Mathematical models in hematology. Klin Wochenschr 1983, 61(19):935-940

67. Wichmann HE: Mathematical Modeling of Cell Proliferation: Stem Cell Regulation in Hemopoiesis. Vol 1: Model Description, Irradiation, Erythropoietic Stimulation. In., vol. 1. Crc Pr I Llc: Boca Raton, Florida; 1985.

68. Meyer G: Charakterisierung der zellkinetischen Wirkungen bei exogener Applikation von Erythropoetin auf die Erythropoese des Menschen mit Hilfe eines mathematischen Kompartimentmodells. Leipzig: Leipzig University; 2004

69. Banks HT, Cole CE, Schlosser PM, Tran HT: Modeling and optimal regulation of erythropoiesis subject to benzene intoxication. Math Biosci Eng 2004, 1(1):15-48.

70. Belair J, Mackey MC, Mahaffy JM: Age-structured and two-delay models for erythropoiesis. Math Biosci 1995, 128(1-2):317-346.

71. Brooks G, Provencher G, Lei J, Mackey MC: Neutrophil dynamics after chemotherapy and G-CSF: the role of pharmacokinetics in shaping the response. J Theor Biol 2012, 315:97-109.

72. Colijn C, Foley C, Mackey MC: G-CSF treatment of canine cyclical neutropenia: a comprehensive mathematical model. Exp Hematol 2007, 35(6):898-907.

73. Colijn C, Mackey MC: A mathematical model of hematopoiesis-I. Periodic chronic myelogenous leukemia. J Theor Biol 2005, 237(2):117-132.

74. Colijn C, Mackey MC: A mathematical model of hematopoiesis: II. Cyclical neutropenia. J Theor Biol 2005, 237(2):133-146.

75. Crauste F, Demin I, Gandrillon O, Volpert V: Mathematical study of feedback control roles and relevance in stress erythropoiesis. J Theor Biol 2010, 263(3):303-316.

76. Engel C, Scholz M, Loeffler M: A computational model of human granulopoiesis to simulate the hematotoxic effects of multicycle polychemotherapy. Blood 2004, 104(8):2323-2331.

77. Glauche I, Cross M, Loeffler M, Roeder I: Lineage specification of hematopoietic stem cells: mathematical modeling and biological implications. Stem Cells 2007, 25(7):1791-1799.

78. Krinner A, Roeder I, Loeffler M, Scholz M: Merging concepts - coupling an agent-based model of hematopoietic stem cells with an ODE model of granulopoiesis. BMC Syst Biol 2013, 7:117.

79. Krzyzanski W, Jusko WJ, Wacholtz MC, Minton N, Cheung WK: Pharmacokinetic and pharmacodynamic modeling of recombinant human erythropoietin after multiple subcutaneous doses in healthy subjects. Eur J Pharm Sci 2005, 26(3-4):295-306.

80. Obeyesekere MN, Berry RW, Spicer PP, Korbling M: A mathematical model of haemopoiesis as exemplified by CD34 cell mobilization into the peripheral blood. Cell Prolif 2004, 37(4):279-294.

81. Scholz M, Engel C, Loeffler M: Modelling human granulopoiesis under poly-chemotherapy with G-CSF support. J Math Biol 2005, 50(4):397-439.

82. Scholz M, Gross A, Loeffler M: A biomathematical model of human thrombopoiesis under chemotherapy. J Theor Biol 2010, 264(2):287-300.

83. Zhuge C, Lei J, Mackey MC: Neutrophil dynamics in response to chemotherapy and G-CSF. J Theor Biol 2012, 293:111-120.

84. Foley C, Bernard S, Mackey MC: Cost-effective G-CSF therapy strategies for cyclical neutropenia: mathematical modelling based hypotheses. $J$ Theor Biol 2006, 238(4):754-763.

85. Sarkar CA, Lauffenburger DA: Cell-level pharmacokinetic model of granulocyte colony-stimulating factor: implications for ligand lifetime and potency in vivo. Mol Pharmacol 2003, 63(1):147-158.

86. Wiczling P, Lowe P, Pigeolet E, Ludicke F, Balser S, Krzyzanski W: Population pharmacokinetic modelling of filgrastim in healthy adults following intravenous and subcutaneous administrations. Clin Pharmacokinet 2009, 48(12):817-826.

87. Shochat $E$, Rom-Kedar $V$ : Novel strategies for granulocyte colony-stimulating factor treatment of severe prolonged neutropenia suggested by mathematical modeling. Clin Cancer Res 2008, 14(20):6354-6363.

88. Scholz M, Ackermann M, Emmrich F, Loeffler M, Kamprad M: Effectiveness of cytopenia prophylaxis for different filgrastim and pegfilgrastim schedules in a chemotherapy mouse model. Biologics 2009, 2009(3):27-37.

89. Talmadge JE, Jackson JD, Borgeson CD, Perry GA: Differential Recovery of Polymorphonuclear Neutrophils, B-Cell and T-Cell Subpopulations in the Thymus, Bone-Marrow, Spleen and Blood of Mice Following Split-Dose Polychemotherapy. Cancer Immunol Immun 1994, 39(1):59-67. 
90. Cullen MH, Billingham $L$, Gaunt $\mathrm{CH}$, Steven NM: Rational selection of patients for antibacterial prophylaxis after chemotherapy. J Clin Oncol 2007, 25(30):4821-4828.

91. Ozer H: The timing of chemotherapy-induced neutropenia and its clinical and economic impact. Oncology 2006, 20:11-15.

92. Rabinowitz AP, Weiner NJ, Tronic BS, Fridman M, Liberman RF, Delgado DJ: Severe neutropenia in $\mathrm{CHOP}$ occurs most frequently in cycle 1: A predictive model. Leuk Lymphoma 2006, 47(5):853-858.

93. Fujiwara K: The platelet-sparing effect of paclitaxel is not related to changes in the pharmacokinetics of carboplatin. Cancer Chemother Pharmacol 2001, 47:22-26.

94. Loi S, Rischin D, Michael M, Yuen K, Stokes K, Ellis AG, Millward MJ, Webster LK: A randomized cross-over trial to determine the effect of Cremophor EL on the pharmacodynamics and pharmacokinetics of carboplatin chemotherapy. Cancer Chemoth Pharm 2004, 54(5):407-414.

95. Scholz M, Engel C, Loeffler M: German High Grade Non-Hodgkin Lymphoma Study G. Br J Haematol 2006, 132(6):723-735.

\section{Submit your next manuscript to BioMed Central and take full advantage of:}

- Convenient online submission

- Thorough peer review

- No space constraints or color figure charges

- Immediate publication on acceptance

- Inclusion in PubMed, CAS, Scopus and Google Scholar

- Research which is freely available for redistribution 